education policy analysis archives A peer-reviewed, independent, open access, multilingual journal

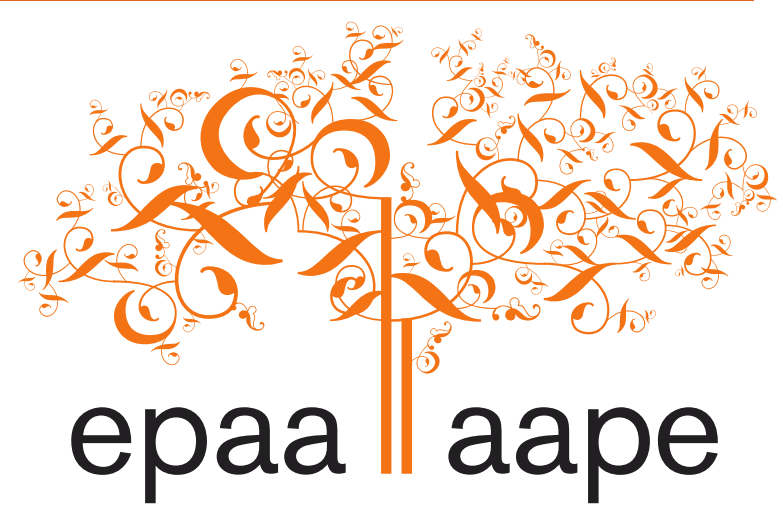

Arizona State University

\title{
The Differential Effects of Parental Involvement on High School Completion and Postsecondary Attendance
}

\author{
Terris Ross \\ U.S. Department of Education ${ }^{1}$ \\ United States
}

Citation: Ross, T. (2016). The differential effects of parental involvement on high school completion and postsecondary attendance. Education Policy Analysis Archives, 24(30). http://dx.doi.org/10.14507/epaa.v24.2030

\begin{abstract}
Previous studies have shown the impact of parental involvement on a number of student achievement, motivation, and engagement outcomes, but the extent to which parental involvement influences high school completion and postsecondary attendance has received less attention in the literature. Filling that gap, this study replicates and extends previous research (Fan \& Williams, 2010) by examining the influence of various dimensions of parental involvement on high school completion and postsecondary attendance (with particular interest in dropouts who later earned GEDs and went on to college). Results show that parents' educational expectations for their children play a significant role in whether students from all backgrounds persist toward completion of high school and whether they attend a postsecondary institution. This study also finds parent participation in school functions to be a significant positive predictor of both high school completion and postsecondary enrollment, while communication between parent and school about
\end{abstract}

\footnotetext{
${ }^{1}$ This study is the result of the author's independent research and the views expressed in the study do not necessarily represent the views of the U.S. Department of Education or the United States. 
children's school problems is negatively associated with both outcomes. The implications for expanding developmentally appropriate and culturally sensitive policies for family and school engagement are discussed.

Keywords: parental involvement; high school completion; postsecondary attendance

Los efectos diferenciales de la participación de los padres en la asistencia post-secundaria y la finalización de la escuela secundaria

Resumen: Estudios previos han demostrado el impacto de la participación de los padres en una serie de logros de los estudiantes, motivación y resultados de la participación, pero el grado en que la participación de los padres influencian la finalización del secundario y post-secundaria ha recibido menos atención en la literatura. Para atender ese problema, este estudio replica y extiende la investigación anterior (Fan \& Williams, 2010) mediante el examen de la influencia de diversas dimensiones de la participación de los padres en la terminación de los estudios y asistencia postsecundaria (con especial interés en los abandonos de estudiantes que más tarde obtuvieron el diploma de finalización GED y que fueron a la universidad). Los resultados muestran que las expectativas educativas de los padres sobre sus hijos tienen un papel importante para que estudiantes de todos los orígenes sociales persistan en la finalización de la escuela secundaria y asistan a una institución de educación superior. Este estudio también revela que la participación de los padres en las actividades escolares puede ser un predictor positivo significativo tanto de la finalización de la escuela secundaria y la matrícula de educación superior, mientras que la comunicación entre padres y escuelas acerca de problemas escolares de los niños se asocia negativamente con ambos resultados. Se discuten las implicaciones para la expansión de las políticas de desarrollo y culturalmente sensibles apropiadas para la participación familiar y escolar.

Palabras clave: participación de los padres; finalización de la preparatoria; asistencia postsecundaria

\section{Os efeitos diferenciais de envolvimento dos pais na conclusão do Ensino Médio e na frequência no Ensino Superior}

Resumo: Estudos anteriores demonstraram o impacto do envolvimento dos pais no desempenho do aluno, na motivação e nos resultados da participação, mas em que medida a participação dos pais influenciam a conclusão do Ensino Médio e do Ensino Superior tem recebido menos atenção na literatura. Para resolver este problema, este estudo replica e estende a pesquisa anterior (Fan \& Williams, 2010), examinando a influência de várias dimensões de envolvimento dos pais na realização de estudos e de frequência no Ensino Superior (com especial interesse em desistências de estudantes que mais tarde obtiveram certificação em exames supletivos e foram para a universidade). Os resultados mostram que as expectativas educacionais dos pais sobre seus filhos têm um lugar importante para que os estudantes de todas as origens sociais persistam em concluir o ensino médio e frequentem a universidade. Este estudo também revela que o envolvimento dos pais nas atividades escolares pode ser um elemento positivo significativo, tanto da conclusão do ensino médio quanto no ingresso no ensino superior, enquanto a comunicação entre pais e escolas sobre problemas escolares das crianças foi negativamente associado em ambos resultados. As implicações para a expansão das políticas de apropriadas e culturalmente sensíveis para participação familiar e escolar são discutidas nesse artigo.

Palavras-chave: envolvimento dos pais; conclusão do ensino; assistência pós-secundário 


\section{Introduction}

Guiding students toward high school completion and college enrollment are major goals of the U.S. education system. The individual and societal benefits of higher education, including higher earnings and employment rates, greater job satisfaction and social mobility, healthier lifestyles, and more active citizens, to name a few, are well documented in the literature (e.g., Baum, Ma, \& Payea, 2013; Brand \& Xie, 2010; Kenkel, 1991; Ou, 2008; Pew Research Center, 2014). For example, in a longitudinal study of high school sophomores in 2002, some $26 \%$ of those with less than high school completion in 2012 were unemployed, compared to $15 \%$ of those with a high school diploma or general educational development (GED) credential and 5\% of those with a bachelor's degree or higher (Lauff \& Ingels, 2013). In terms of income, 7\% of those with less than high school completion earned an income of $\$ 40,000$ or more from employment, compared to $14 \%$ with a high school diploma or GED and 33\% of those with a bachelor's degree or higher. Receiving public assistance also differentiated the three groups as $47 \%$ of cohort members with less than high school completion had received public assistance in 2011, compared to $32 \%$ of those with a high school diploma or GED and 5\% of those with a bachelor's degree or higher. These statistics are not surprising, given that federal agencies, such as the Bureau of Labor Statistics (BLS) and the U.S. Department of Education, have reported similar patterns for many years (BLS, nd; Kena et al., 2015).

Given these large disparities by educational attainment, factors that lead to the decision to drop out of school have been studied extensively (e.g., Alexander, Entwisle, \& Horsey, 1997; BattinPearson et al., 2000; Dynarski \& Gleason, 1999; Fan \& Wolters, 2014; Henry, Knight, \& Thornberry, 2012; Neild, Stoner-Eby, \& Furstenberg, 2008; Rumberger \& Larson, 1998). Student risk factors include living in a single parent household, being economically disadvantaged, and experiencing grade retention, limited English proficiency, emotional and/or behavioral disorders, and learning disabilities, to name a few. However, studies have also found that, when asked, students cite a number of school, family, and work-related reasons for dropping out of school (e.g., Malkus \& Sen, 2012), resulting in the need for multiple approaches to address this problem. In particular, the National Dropout Prevention Center/Network (NDPC/N), a well-known and respected clearinghouse for research in this area, promotes 15 strategies shown to be effective at reducing dropout behavior. These strategies range from early interventions, such as increasing preschool participation and family engagement, to making the most of instruction, by providing professional development for teachers of at-risk youth (for more information, see http://dropoutprevention.org/effective-strategies/).

Disengagement from school is not only of interest to researchers and practitioners, but also to policymakers who are working to both understand and find solutions to this problem, which disproportionately impacts some student populations (e.g., minorities and low-income students), compared to others. There is strong agreement among federal policymakers that an important part of any strategy to reduce dropout rates (overall and particularly among vulnerable subgroups), is for school leaders to improve family-school relations and increase parental involvement in education (e.g., deCastro \& Catsambis, 2009; Hill \& Chao, 2009; Hill, Tyson, \& Bromell, 2009; HooverDempsey, Ice, \& Whitaker, 2009; $107^{\text {th }}$ Congress, 2002). In particular, the 2002 reauthorization of the Elementary and Secondary Education Act (ESEA), better known as the No Child Left Behind Act (NCLB; $107^{\text {th }}$ Congress, 2002), mandated that states seeking funding for Title I (i.e., lowincome) schools identify and implement practices for involving parents that are "based on the most current research that meets the highest professional and technical standards, on effective parental 
involvement that fosters achievement to high standards for all children.” (Section 1111.d). The 2015 reauthorization, known as the Every Student Succeeds Act, or ESSA, maintains this commitment to parent and family engagement activities $\left(114^{\text {th }}\right.$ Congress, 2015). Hence, the effect of parental involvement on student achievement and dropout behavior is of continuing interest to practitioners and policymakers alike.

\section{Parental Involvement during the Adolescent Years}

The belief that children benefit from their parents' involvement in school-related activities is supported by research, particularly studies of the impact of parental involvement on students' academic outcomes, behavior, motivation, engagement, and self-efficacy (e.g., Domina, 2005; Fan \& Williams, 2010; Jeynes, 2005). However, research also shows a steady decline in parental involvement once children reach the middle and high school years (e.g., Eccles et al., 1993; Epstein \& Dauber 1991; Spera, 2005; U.S. Department of Education, 1998). During this time, adolescents begin to express a desire for more independence and autonomy - feelings that are reinforced by the changes in school structure and expectations for independent work that students encounter in secondary school settings (Epstein \& Sanders, 2002). Unfortunately, using developmentally appropriate strategies to help adolescents successfully transition from elementary to middle (or from middle to high) school does not appear to be a widespread practice. Rather, middle and high school programs aimed at increasing parental involvement are often uninformed by research and best practice for how to effectively collaborate with parents to support adolescent achievement (Hill \& Chao, 2009). At the same time, there is less research evidence on the effects of parental involvement for secondary school outcomes than there is for elementary school outcomes. Thus, not only is it challenging to find ways to keep parents involved during these years, but a greater understanding of the relationship between parental involvement and secondary outcomes - such as high school completion and postsecondary attendance - is also needed.

\section{Parental Involvement and Student Outcomes}

Studies have shown the positive impact of parental involvement on a number of proximal and distal student outcomes, including reading and mathematics achievement (Jeynes, 2005; Sheldon \& Epstein, 2005; Sirvani, 2007; Sui-Chu \& Willms, 1996; Yan \& Lin, 2005), student behavior in school (Domina, 2005), school attendance, preparation for class, and course completion (Simon, 2001), student motivation, academic self-efficacy, and engagement (Fan \& Williams, 2010; Gonzalez-DeHass et al, 2005), and middle school dropout behavior (Rumberger, 1995). However, not all parental involvement activities have positive effects (Domina, 2005; Fan, 2001; Izzo, Weissberg, Kasprow, \& Fendrich, 1999). For example, in an early childhood education study, the quality of parent-teacher interactions predicted improvements in student achievement and behavior but frequent parent-teacher contact was associated with declines in acceptable classroom behavior (Izzo et al., 1999). In Fan's (2001) study, parents' aspirations for their children's educational attainment exceeded all other aspects of parental involvement in predicting middle school students' academic growth, even after controlling for socioeconomic status (SES). However, some parental involvement behaviors (e.g., education-related communication with child, volunteering at child's school) were not as consistently predictive of student academic growth, and others (e.g., frequent contact with child's school) had negative effects on student achievement. Another study on the influence of parental involvement on student achievement of elementary school children found that the statistically significant positive effects of activities such as volunteering at school, and checking 
and helping children with homework actually become nonsignificant (and even negative), after controlling for children's prior academic achievement and school and family background characteristics (Domina, 2005). Clearly, more research is needed to replicate and extend the findings in this area and to examine outcomes (e.g., high school completion and postsecondary attendance) for students at higher levels of education than elementary and middle school, where much of the existing research is focused.

\section{Parental Involvement Differences by Race/Ethnicity and SES}

Previous research has also examined parental involvement across racial/ethnic groups; however, the evidence is mixed at best. While overall, it may appear that parents of black and Hispanic youth are less involved than white parents (e.g., Yan \& Lin, 2005), some studies show after controlling for other background variables - that black and Hispanic parents may often be more involved than White parents in the education of their children (e.g., Sui-Chu \& Willms, 1996). Still, other studies show no differences by race/ethnicity at all (e.g., Hill et al., 2004). Additionally, research on the effectiveness of parental involvement across different socioeconomic groups is also inconclusive. That is, well-educated and affluent parents tend to draw on their experiences and understanding of education processes and operations to both advocate for their children and engage in practices that align with school efforts. However, research has also shown those same practices may be observed among less-educated/lower-income parents, once they are taught how to navigate the complex system of American schools and how to support their children in ways that promote academic success (Nicolau \& Ramos, 1990; Olivos, 2006; Smith, Robbins, Stagman, \& Mahur, 2013). Further, varying cultural perceptions of parent and teacher roles, as well as language differences and school and community barriers to parental involvement, may also contribute to differences in parental involvement by race/ethnicity and SES. For example, in many Spanishspeaking countries, teachers and school leaders are viewed as education experts, and therefore many Hispanic parents in the U.S. (both native and foreign-born) may defer to, rather than question or oppose, school officials when making decisions for their children (deCastro \& Catsambis, 2009). Unfortunately, this kind of behavior can be mistaken for apathy on the part of parents who may just be less comfortable than other parents when it comes to directing their children's education. In this, and possibly other ways, existing theory and research are somewhat limited in explaining apparent differences between racial/ethnic and socioeconomic groups, which can hinder efforts to develop positive parent-school relationships.

\section{Dimensions and Types of Parental Involvement}

Another challenge to measuring parental involvement is that there is no consistent definition of what it entails. In general, researchers agree that parental involvement encompasses a whole host of activities and behaviors that promote the academic and social success of one's children (Fishel \& Ramirez, 2005) and that it is better understood as a multidimensional construct (Epstein, 1995; Fan \& Williams, 2010; Grolnick \& Slowiaczek, 1994). Epstein (1995) - one of the most widely cited researchers to first suggest a multidimensional framework for parental involvement - ultimately conceptualized it as six types of activities that are essential to a comprehensive program of a family, school, and community partnership: (1) parenting, (2) communicating, (3) volunteering, (4) learning at home, (5) decision making and (6) collaborating with the community. According to Epstein, students are best served when schools help families establish supportive home environments for learning, provide two-way systems of communication about school programs and student progress, 
actively recruit and organize help from parents, facilitate at-home learning, involve parents from all race and socioeconomic backgrounds as representatives and leaders on school committees, and identify and effectively integrate community resources to strengthen school programs. Obviously, these practices, when implemented, are meant to more deeply engage parents in the school community than simply providing information through newsletters and progress reports. Other researchers (e.g., Henderson, 2002; Olivos, 2006) share this perspective, noting that authentic programs for increasing school-family engagement will recognize and value differences in the ways that parents - especially those of diverse racial/ethnic groups - interact with their children's schools. While Epstein (1995) and others (e.g., Singh, Bickley, Trivette, Keith, \& Keith, 1995) developed theories based either on their intuition about what should logically constitute parental involvement or by analyzing the content of questionnaire items, Fan (2001) was one of the first to empirically test these theories and demonstrate - through exploratory factor analysis and latent growth curve analysis - the existence of multiple and distinct dimensions of parental involvement and their effects on students' academic growth in high school. Using 14 survey items related to parental involvement from NCES' National Education Longitudinal Study of 1988 (NELS:88), Fan identified seven dimension of parental involvement: (1) TV rules, (2) Communication, (3) Contact with School, (4) PTA, (5) Volunteer, (6) Supervision, and (7) Education Aspiration. Fan's study found comparable levels of parental involvement across racial/ethnic groups and that parents' aspirations for their children's educational attainment was a consistent and positive predictor of students' academic growth in reading, mathematics, science and social studies from 1988 to 1992.

More recently, Fan and Williams (2010) used a similar approach as Fan (2001) in examining the differential effects of eight parental involvement dimensions on student motivation, academic self-efficacy, and engagement in a nationally representative sample of high school sophomores. The dimensions studied included: (1) parental aspirations for their children's educational attainment, (2) parent participation in school functions, (3) family rules reflecting parental home supervision, (4) parental advising, (5) parent participation in their children's extracurricular activities, (6) parentschool communication regarding children's problems at school, (7) school-initiated contact with parents regarding benign school issues, and (8) parent-initiated contact with schools regarding benign school issues. In this later study, Fan and Williams (2010) separated parent-school communications regarding children's problems at school from parent-school communications regarding benign issues in order to examine the negative relationship between parent-school communication and student academic outcomes (i.e., behavior and achievement) uncovered in earlier studies (Fan, 2001; Izzo et al., 1999). Also, Fan and Williams separately examined parentinitiated and school-initiated contact regarding benign school issues as a way of investigating the differential effects of each on student motivation, academic self-efficacy, and engagement. Their results demonstrated - once again - the powerful association between parents' educational aspirations for their children and student academic outcomes. Parent aspirations and school-initiated contact with parents showed strong positive effects on students' school engagement and their intrinsic motivation and self-efficacy towards mathematics and English. However, similar to previous research, parent-school contact regarding students' school problems was negatively associated with all outcomes studied. Finally, parental advising positively predicted students' academic self-efficacy and intrinsic motivation in English, while family rules for watching television positively predicted students' intrinsic motivation and engagement towards mathematics and English. 


\section{Parental Involvement, High School Completion, and Postsecondary Attendance}

All of the above cited studies show the effects of parental involvement - whether positive or negative - on a number of student achievement, motivation, and engagement outcomes. However, the extent to which specific parental contact and involvement practices influence middle and high school completion and postsecondary attendance has received less attention in the literature. Rumberger's (1995) study on the differential effects of parental involvement activities on middle school dropout behavior is a notable exception. He found that the most powerful parental involvement factors - among those studied - were the extent to which parents participate in school parent-teacher organizations and act as volunteers at their child's school. Students with less academic support and supervision were 34\% more likely to drop out than other students. Also, students whose parents had low educational expectations for them (i.e., only expecting high school graduation) were more than five times as likely as other students to drop out of school in the eighth grade. Additionally, Ross et al (2012) investigated the effects of a number of variables thought to impact immediate postsecondary enrollment after high school (e.g., GPA, mathematics achievement, previous grade retention, school absenteeism, participation in high school sports and extracurricular activities, discussing coursework with parents, working at a job more than 30 hours per week, and having close friends who dropped out of school). The study showed that, after controlling for various student and family background variables, students who often discussed school courses with their parents had $44 \%$ higher odds of immediate enrollment in postsecondary education, compared to those who never had these discussions with their parents. These few studies notwithstanding, more research is needed to understand how parental involvement positively influences secondary school outcomes and how education policies - such as Title I provisions under ESEA - can be leveraged to capitalize on those relationships.

\section{Study Purpose}

This study replicates and extends previous research by examining the impact of various dimensions of parental involvement (as defined in Fan \& Williams, 2010) on high school completion and postsecondary attendance (with particular interest in dropouts who later earned GEDs and went on to college). This study fills an important gap in the emerging literature on parental involvement and has implications for expanding developmentally appropriate and culturally sensitive policies for family and school engagement. The study answers the following research question:

Are specific dimensions of parental involvement previously shown to impact the likelihood of middle school dropout behavior (Rumberger, 1995) and/or shown to increase high school students' academic self-efficacy, engagement, and intrinsic motivation in mathematics and English (Fan \& Williams 2010) similarly associated with high school completion and postsecondary attendance?

The answer to this question may depend - to some extent - on other factors, such as student and family background characteristics. In fact, among a nationally representative sample of high school sophomores in 2002, Malkus and Sen (2012) showed that high school completion status (in 2006) varied by a number of student characteristics. For example, male students and black, Hispanic, and low SES students were more often represented among dropouts than they were among high school graduates or GED recipients. More specifically, Malkus and Sen reported that $49 \%$ of high school graduates were male compared to $59 \%$ of GED recipients and $60 \%$ of dropouts. In terms of race/ethnicity, 13\% of high school graduates were Black, compared to 16\% of GED recipients and 18\% of dropouts. The percentages for Hispanic/Latino high school graduates, 
GED recipients, and dropouts were 14\%,16\%, and 33\%, respectively. That study also reported that $22 \%$ of high school graduates were from the lowest socioeconomic status quartile, compared to $35 \%$ of GED recipients and $55 \%$ of dropouts who also came from low-income families.

Furthermore, parental involvement has been shown to vary by race/ethnicity, socioeconomic status, and family structure (Aston \& McLanahan, 1991; Desimone, 1999; Zellman \& Waterman, 1998). Given these findings, this study controls for the influence of student and family background variables (i.e., race/ethnicity, sex, and family income).

\section{Methodology: Data, Measures, and Analysis}

\section{Data}

To replicate and extend the analysis conducted in Fan \& Williams (2010), I used data from the Education Longitudinal Study of 2002 (ELS: 2002), a nationally representative study of tenth graders in 2002 and 12th graders in 2004 and which followed the cohort through 2012, when most members would have been approximately 26 years old (Lauff \& Ingels, 2013). ELS: 2002 - one of many school-based longitudinal studies conducted by the National Center for Education Statistics (NCES) - followed students as well as high school dropouts, monitoring their transitions to postsecondary education, the labor force, and family formation. The four rounds of data collection on this cohort of high school sophomores include the base year in 2002, the first follow-up in 2004, the second follow-up in 2006, and the third follow-up in 2012.

In addition to collecting information from the cohort, ELS includes data from questionnaires administered to the students' parents, teachers, librarians, and school administrators. The base year (2002) sample included 16,197 tenth graders, weighted to represent the approximately 3 million high school sophomores enrolled in U.S. schools. Among those sampled, 15, 362 students and 13, 488 parents completed questionnaires. In the weighted sample, 50.0\% of students were female and 50.0\% were male; $60.3 \%$ were White, $15.9 \%$ were Hispanic/Latino, $14.4 \%$ were Black, 4.2\% were Asian/ Pacific Islander, $1.0 \%$ were American Indian/Alaska Native, and $4.3 \%$ were of two or more races (Ingels, Burns, Chen, Cataldi, \& Charleston, 2005). All four rounds of data collection achieved weighted response rates of $84 \%$ and above. Nonresponse bias analyses were conducted at each round to adjust for nonresponse so that the data could be used with confidence. During this process, NCES identified 78 high-nonresponse student questionnaire variables in the dataset. Among these variables, the nonresponse bias analysis detected a bias of $5 \%$ or higher in less than one half of $1 \%$ of the observations. For more information on the nonresponse bias analysis, and other possible limitations of the dataset, see the ELS data file documentation (Ingels et al., 2014).

Similar to previous NCES longitudinal studies, ELS: 2002 surveyed parents about specific activities they engage in with their tenth grader. The availability of multiple items related to parental involvement makes it possible to examine how the various dimensions of parental involvement may affect student outcomes, including high school completion and postsecondary attendance.

\section{Measures: Parental Involvement Variables}

The types of parental involvement I examine here include (1) parent participation in their children's extracurricular activities, (2) parental advising, (3) parent-school communication regarding children's problems at school, (4) school-initiated contact with parents regarding benign school issues, (5) parent-initiated contact with schools regarding benign school issues, (6) parent 
participation in school functions, (7) parental aspirations for their children's educational attainment, and (8) family rules reflecting parental home supervision. In the base year of ELS: 2002, parents responded to questionnaire items asking about various activities that they had engaged in with their child or their child's school. The selected questionnaire items for this study are those used to represent the eight dimensions of parental involvement, as defined by Fan and Williams (2010). These items are similar to those used in a number of empirical studies and have been shown to have acceptable reliability and validity (e.g., Fan, 2001; Hill \& Craft, 2003; Yan \& Lin, 2005). Table 1 provides a list of the items I used to measure each parental involvement dimension (including the internal consistency estimates reported in Fan \& Williams, 2010). The parental aspiration dimension is a composite variable that NCES created (and imputed using a weighted sequential hot deck procedure) for the ELS: 2002 dataset. Unfortunately, the family rules dimension, composed of items measuring the extent to which parents reported having four specific rules for their tenth-grader (i.e., maintaining a certain grade average, doing homework, doing household chores, and watching television) did not exhibit adequate internal consistency (Cronbach's alpha $=.59$ ) in the Fan and Williams (2010) study. Therefore, in this study, I - like Fan and Williams (2010) - treated the four variables separately in the analyses. 
Table 1

Selected ELS: 2002 Questionnaire Items Used to Measure 7 Dimensions of Parental Involvement

\begin{tabular}{|c|c|}
\hline Dimension & Questionnaire Items \\
\hline $\begin{array}{l}\text { Parent } \\
\text { participation in } \\
\text { extracurricular } \\
\text { activities with } \\
\text { children } \\
\text { (Cronbach's } \\
\text { alpha }=.76)\end{array}$ & $\begin{array}{l}\text { Looking back over the past year, how frequently did you and your tenth } \\
\text { grader participate in the following activities together? } \\
(1=\text { Never, } 2=\text { Rarely, } 3=\text { Sometimes, } 4=\text { Frequently) } \\
\text { Attending concerts, plays, or movies outside of school (BYP57C) } \\
\text { Attending sporting events outside of school (BYP57D) } \\
\text { Attending family social functions (party, wedding) (BYP57F) } \\
\text { Taking day trips or vacations (BYP57G) } \\
\text { Working on a hobby or playing sports (BYP57H) } \\
\text { Going to restaurants/eating out (BYP57J) } \\
\text { Doing something else fun together (BYP57L) }\end{array}$ \\
\hline
\end{tabular}

\begin{tabular}{ll}
\hline $\begin{array}{l}\text { Parental advising } \\
\text { (Cronbach's }\end{array}$ & $\begin{array}{l}\text { In the first semester or term of this school year, how often have you and/or } \\
\text { alpha }=.77)\end{array}$ \\
& your spouse/partner provided advice or information about the following to \\
& Selecting courses or programs at school (BYP56A) \\
& Plans and preparation for college entrance exams such as ACT, SAT, or \\
& ASVAB (BYP56B) \\
& Applying to college or other schools after high school (BYP56C) \\
& Specific jobs your tenth grader might apply for after high school (BYP56D) \\
& Community, national, and world events (BYP56E) \\
& Things that are troubling your tenth grader (BYP56F)
\end{tabular}

\footnotetext{
Parent-school communication concerning children's school problems (Cronbach's alpha $=.76)$ Since your tenth grader's school opened last fall, how many times have you or your spouse/partner been contacted by the school (or you or your spouse/partner contacted the school) about the following? $(1=$ None, $2=$ Once or twice, $3=$ Three or four times, $4=$ More than four times)

Your tenth grader's poor performance in school (BYP52A and BYP53A) Your tenth grader's problem behavior in school (BYP52F and BYP53F)

School-initiated contact with parents and Parent-initiated contact with school (Cronbach's Since your tenth grader's school opened last fall, how many times have you or your spouse/partner been contacted by the school (or you or your spouse/partner contacted the school) about the following? $(1=$ None, $2=$ Once or twice, $3=$ Three or four times, $4=$ More than four times) alpha $=.65$ and Your tenth grader's school program for this year (BYP52B and BYP53B) .71 , respectively) Your tenth grader's course selection for entry into college, vocational, or technical school after completing high school (BYP52D and BYP53D) Information on how to help your tenth grader at home with specific skills or homework (BYP52I and BYP53I)
} 
Table 1 continued

Selected ELS: 2002 Questionnaire Items Used to Measure 7 Dimensions of Parental Involvement

\begin{tabular}{ll}
\hline Dimension & Questionnaire Items \\
\hline Parent & In this school year, do you or your spouse/partner do any of the following?
\end{tabular}

participation in $\quad(0=$ No, $1=$ Yes $)$

school functions

(Cronbach's Belong to the school's parent-teacher organization (BYP54A)

alpha $=.72) \quad$ Attend meetings of the parent-teacher organization (BYP54B)

Take part in the activities of the parent-teacher organization (BYP54C)

Act as a volunteer at the school (BYP54D)

Belong to any other organization with several parents from your tenth

grader's school (for example, neighborhood or religious organizations)

(BYP54E)

\begin{tabular}{|c|c|}
\hline $\begin{array}{l}\text { Parental } \\
\text { aspirations for } \\
\text { children's } \\
\text { postsecondary } \\
\text { education }\end{array}$ & $\begin{array}{l}\text { How far in school the parent wants their tenth grader to go (BYPARASP) } \\
1=\text { Less than high school graduation } \\
2=\text { High school graduation or GED only } \\
3=\text { Attend or complete } 2 \text {-year college } / \text { school } \\
4=\text { Attend college, } 4 \text {-year degree incomplete } \\
5=\text { Graduate from college } \\
6=\text { Obtain master's degree or equivalent } \\
7=\text { Obtain PhD, MD, or other advanced degree }\end{array}$ \\
\hline Family Rules & $\begin{array}{l}\text { Are there family rules that are enforced for your tenth grader about any of } \\
\text { the following activities? ( } 0=\text { No, } 1=\text { Yes) } \\
\text { Maintaining a certain grade average (BYP69A) } \\
\text { Doing homework (BYP69B) } \\
\text { Doing household chores (BYP69C) } \\
\text { Watching television (BYP69D) }\end{array}$ \\
\hline
\end{tabular}

\section{Measures: Student and Family Background Variables}

The student and family background variables I used in this analysis include sex, race/ethnicity, and socioeconomic status (SES). For all three of these variables, missing values were imputed by NCES before releasing the ELS: 2002 dataset. Sex was constructed from the base-year student questionnaire and when missing, NCES determined sex using the school roster or by logical imputation using the student's first name. Race/ethnicity was also self-reported and imputed by NCES using similar procedures as for the sex variable. For the current study, I used the following six race categories: White, American Indian/Alaska Native, Asian/Pacific Islander, Black, Hispanic, and two or more races. With the exception of the Hispanic category, all race categories exclude students of Hispanic or Latino origin. The variable I used to describe students' SES is a composite variable within the ELS dataset that NCES constructed from five component variables: father's education level, mother's education level, family income, father's occupation, and mother's occupation. Data for all five components were collected on the parent questionnaire and imputed 
when missing. For more information on NCES imputation procedures, see the ELS data file documentation (Ingels et al., 2014).

\section{Measures: Dependent Variables}

In this study, I examine the effects of various parental involvement behaviors on two educational outcomes - high school completion (either through high school diploma or GED) and postsecondary attendance by 2006. High school completion was measured by NCES using selfreported data from the second follow-up student questionnaire in 2006. Where missing, data from transcripts or the first follow-up questionnaire in 2004 were used. Postsecondary attendance status was taken from the second follow-up student questionnaire, and is based on students' self-report of whether they had ever attended a postsecondary institution since high school. Where missing, NCES provides imputed data in the ELS: 2002 dataset.

\section{Analysis}

Similar to Fan and Williams (2010), the current study accounts for the complex, two-stage (i.e., school selection, followed by student selection) sampling design employed by ELS: 2002. I applied the full sample weight (F2BYWT) to all estimates and used Taylor-linearized variance estimation (using primary sampling unit and strata weighting) to produce unbiased estimates of the standard errors reported in this paper. The Taylor series approximation technique makes appropriate adjustments for participant nonresponse and unequal probabilities of selection - two complex survey issues that can seriously affect variance estimation, if not adequately addressed. I conducted all of the analyses using complex survey (i.e., SVY) commands within the STATA 13 statistical software package (StataCorp, 2013) and I included appropriate weights (at the stratum, cluster, and student level) to adjust for nonresponse and the unequal probability of selection associated with ELS: 2002.

As is common with many large-scale data sets, ELS: 2002 contains missing data across a number of variables, including the parental involvement questionnaire items involved in this study. The amount of missing data (across all variables in this study) ranged between $0.2 \%$ and $25.9 \%$ (unweighted), which is large enough to warrant closer attention (Graham \& Hofer, 2000). Fortunately, there are many options for addressing missing data, such as traditional methods of listwise or pairwise deletion, means substitution, etc. However, these approaches can result in drastic reductions in sample size and do not account for nonrandom missing data. The risks of producing biased estimates using these methods - and the advantages of other approaches, such as multiple imputations - are well-documented (Baraldi \& Enders, 2010; Fichman \& Cummings, 2003; Howell, 2007; Little \& Rubin, 1987; Rubin, 1987).

To avoid some of the issues associated with these approaches, in this study I employed sequential regression multivariate imputation (SRMI) to generate five sets of imputed data for the analysis. SRMI is a flexible technique that can handle variables of different types (e.g., categorical, continuous) when selecting appropriate regression models to predict missing data. Another advantage is that SRMI makes use of all of the information in a dataset, when imputing data for each missing value. I conducted the SRMI method using the "mi impute chained" command in STATA 13, which supports multivariate imputation using chained equations (ICE). For more information on the SRMI procedure, see Raghunathan, Lepkowski, Van Hoewyk \& Solenberger (2001).

After creating the parental dimension scales from the individual questionnaire items, I employed the mi impute chained procedure in STATA 13 to produce the five imputed datasets. 
Then, I performed descriptive analyses to describe various characteristics and outcomes for the sample.

To study the effects of parental involvement on high school completion via diploma or GED certificate, I conducted logistic regression analyses using data for the entire cohort of sophomores in 2002 and then separately on the subpopulation of non-diploma recipients (primarily sophomores who dropped out of high school at some point between the base year and second follow up data collections in 2002 and 2006, respectively). To study the effects of parental involvement on college-going by 2006, I performed similar analyses for the sophomore cohort and the subpopulation of non-diploma recipients. Additionally, I conducted each logistic regression analysis across the five imputed datasets using the "mi estimate: svy" command in STATA 13. In the analyses, I controlled for student and family background variables, namely sex, race/ethnicity, and SES.

Unless otherwise indicated, study results are based on imputed data from the five generated datasets. Only statistically significant differences are highlighted in the comparisons. However, STATA's mi estimate command does not support t-tests for comparing estimates with imputed data. Therefore, in the descriptive analysis of means and percentages, I compared the 95\% confidence intervals for each of the parental involvement variable estimates. I present standardized regression coefficients for the multivariate analyses.

\section{Results}

Table 2 shows the weighted, non-imputed, percentage of spring 2002 tenth graders, by high school completion status in 2006. Eighty-eight percent (88\%) of sophomores in 2002 had earned a high school diploma by 2006 , compared to $4 \%$ who dropped out of high school but later received a GED and 8\% with less than high school completion.

Table 2

Percentage of spring 2002 sophomores, by bigh school completion status in 2006

\begin{tabular}{|c|c|c|c|c|c|}
\hline \multicolumn{2}{|c|}{ High school graduates } & \multicolumn{2}{|c|}{ GED recipients } & \multicolumn{2}{|c|}{ Non-completers $^{1}$} \\
\hline Percentage & $\mathrm{SE}$ & Percentage & SE & Percentage & SE \\
\hline 87.8 & 0.45 & 3.9 & 0.22 & 8.2 & 0.39 \\
\hline
\end{tabular}

Note: Table values represent weighted, non-imputed data.

${ }^{1}$ Includes students receiving a certificate of attendance, and those still enrolled in high school in 2006.

Students receiving certificates of attendance and those still enrolled in high school in 2006 represent approximately one percent of the unweighted study sample.

Table 3 a presents the means and standard errors for each of the parental involvement variables, overall and by high school completion status. Among the four types of parental involvement that parents were asked to rate on a 4-point scale, overall (and across all high school completion categories) the highest averages were reported for parent participation in extracurricular activities with children $(M=3.06, S E=.007$; see Appendix A-1 for $95 \%$ confidence intervals). That is, on average, parents reported being "sometimes" involved with their children's extracurricular activities. Averages for the other 4-point composite variables follow: parent-school communication concerning children's school problems $(M=1.32, S E=.007)$, school-initiated contact with parents $(M=1.33$, SE $=.006)$, and parent-initiated contact with school $(M=1.37, S E=.006)$. Overall, communication between parents and schools was infrequent (i.e., less than "once or twice" during 
the school year). Parental advising - which was rated on a 3-point scale - averaged 2.27 points overall, with a standard error of .006.

Table $3 \mathrm{a}$

Means and standard errors for parental involvement variables, by high school completion status in 2006

\begin{tabular}{|c|c|c|c|c|c|c|c|c|}
\hline & \multicolumn{2}{|c|}{ Total } & \multicolumn{2}{|c|}{$\begin{array}{l}\text { High School } \\
\text { Diploma } \\
\text { Recipients }\end{array}$} & \multicolumn{2}{|c|}{ GED recipients } & \multicolumn{2}{|c|}{ Non-Completers 1} \\
\hline $\begin{array}{l}\text { Parental Involvement } \\
\text { Variable }\end{array}$ & $\mathrm{M}$ & $\mathrm{SE}$ & $\mathrm{M}$ & $\mathrm{SE}$ & $\mathrm{M}$ & $\mathrm{SE}$ & $\mathrm{M}$ & SE \\
\hline $\begin{array}{l}\text { Parent participation in } \\
\text { extracurricular } \\
\text { activities with children }\end{array}$ & 3.06 & 0.007 & 3.08 & 0.007 & 2.94 & 0.035 & 2.85 & 0.027 \\
\hline Parental advising & 2.27 & 0.006 & 2.28 & 0.006 & 2.24 & 0.032 & 2.15 & 0.028 \\
\hline $\begin{array}{l}\text { Parent-school } \\
\text { communication } \\
\text { concerning children's } \\
\text { school problems }\end{array}$ & 1.32 & 0.007 & 1.26 & 0.006 & 1.76 & 0.059 & 1.80 & 0.041 \\
\hline $\begin{array}{l}\text { School-initiated } \\
\text { contact with parents }\end{array}$ & 1.33 & 0.006 & 1.33 & 0.007 & 1.34 & 0.032 & 1.38 & 0.023 \\
\hline $\begin{array}{l}\text { Parent-initiated } \\
\text { contact with school }\end{array}$ & 1.37 & 0.006 & 1.36 & 0.007 & 1.50 & 0.036 & 1.43 & 0.028 \\
\hline $\begin{array}{l}\text { Parent participation in } \\
\text { school functions }\end{array}$ & 0.29 & 0.005 & 0.30 & 0.005 & 0.21 & 0.015 & 0.19 & 0.012 \\
\hline $\begin{array}{l}\text { Parental aspiration for } \\
\text { children's } \\
\text { postsecondary } \\
\text { education }\end{array}$ & 5.32 & 0.016 & 5.38 & 0.156 & 4.97 & 0.075 & 4.83 & 0.061 \\
\hline $\begin{array}{l}\text { Family rules for } \\
\text { maintaining grade }\end{array}$ & 0.82 & 0.005 & 0.82 & 0.005 & 0.81 & 0.027 & 0.81 & 0.023 \\
\hline $\begin{array}{l}\text { Family rules for doing } \\
\text { homework }\end{array}$ & 0.93 & 0.004 & 0.93 & 0.004 & 0.91 & 0.018 & 0.93 & 0.012 \\
\hline $\begin{array}{l}\text { Family rules for doing } \\
\text { household chores }\end{array}$ & 0.88 & 0.004 & 0.88 & 0.004 & 0.93 & 0.015 & 0.92 & 0.011 \\
\hline $\begin{array}{l}\text { Family rules for } \\
\text { watching television }\end{array}$ & 0.65 & 0.007 & 0.64 & 0.007 & 0.63 & 0.039 & 0.69 & 0.021 \\
\hline
\end{tabular}

Note: Table values represent averaged estimates from five imputed datasets.

${ }^{1}$ Includes students receiving a certificate of attendance, and those still enrolled in high school in 2006. Students receiving certificates of attendance and those still enrolled in high school in 2006 represent approximately one percent of the unweighted study sample. 
Parents' educational aspirations for their children were measured using a seven-point scale (ranging from less than high school graduation to Ph.D., M.D., or other advanced degree). On average, parents aspired for their children to at least graduate from college $(M=5.32)$, although this item appears to vary more across the sample $(S E=.016)$ than the other parental involvement dimensions. To further examine this finding, I calculated parents' educational aspirations for their children, by race/ethnicity and SES. Table $3 \mathrm{~b}$ shows the resulting means and standard errors. Compared to other racial/ethnic groups, the parents of Asian/Pacific Islander $(M=5.76, S E=$ .036) and black $(M=5.55, S E=.040)$ students reported the highest expectations for their tenthgrader (see Appendix A-2 for 95\% confidence intervals). Table 3c shows that, after combining categories 5 (graduate from college), 6 (obtain master's degree or equivalent), and 7 (obtain $\mathrm{PhD}$, $\mathrm{MD}$, or other advanced degree) into one category (bachelor's degree or higher), the highest percentage was also observed for Asian/Pacific Islander students (94\%). The percentage for black students $(89 \%)$ was not statistically different from White, American Indian/Alaska Native, Hispanic, or students of two or more races (see Appendix A-3 for 95\% confidence intervals).

Table 3b

Means and standard errors of parents' aspirations for their tenth grader's postsecondary education, by race/ ethnicity and SES

\begin{tabular}{lcc}
\hline & $\begin{array}{c}\text { Parents' aspirations for their tenth grader's } \\
\text { postsecondary education }\end{array}$ \\
\hline Student Characteristic & M & SE \\
\hline Race/ethnicity & 5.23 & 0.021 \\
$\quad$ White & 5.16 & 0.171 \\
$\quad$ American Indian/Alaska Native & 5.76 & 0.036 \\
Asian/Pacific Islander & 5.55 & 0.040 \\
Black & 5.34 & 0.037 \\
Hispanic & 5.32 & 0.072 \\
$\quad$ Two or more races & & \\
Socioeconomic Status (SES) Quartile & 5.03 & 0.034 \\
Lowest quartile & 5.18 & 0.029 \\
Second quartile & 5.39 & 0.023 \\
Third quartile & 5.70 & 0.020 \\
Highest quartile &
\end{tabular}

Note: Table values represent averaged estimates from five imputed datasets.

${ }^{1}$ Based on (BYPARASP) How far in school the parent wants their tenth grader to go, where

$1=$ Less than high school graduation

$2=$ High school graduation or GED only

$3=$ Attend or complete 2 -year college/school

$4=$ Attend college, 4-year degree incomplete

$5=$ Graduate from college

$6=$ Obtain master's degree or equivalent

$7=$ Obtain $\mathrm{PhD}, \mathrm{MD}$, or other advanced degree 
Table 3c

Percentage of spring 2002 sophomores whose parents aspired for them to attain a bachelor's degree or higher, by race/ethnicity and SES

\begin{tabular}{lcc}
\hline & $\begin{array}{c}\text { Parents' aspirations for their tenth grader to } \\
\text { attain a bachelor's degree or higher }\end{array}$ \\
\hline Student Characteristic & Percentage & SE \\
\hline Total & 86.42 & 0.451 \\
Race/ethnicity & & \\
White & 85.74 & 0.601 \\
American Indian/Alaska Native & 81.93 & 4.597 \\
Asian/Pacific Islander & 93.64 & 0.910 \\
Black & 88.61 & 0.953 \\
Hispanic & 85.93 & 0.942 \\
Two or more races & 84.66 & 2.025 \\
& & \\
Socioeconomic Status (SES) Quartile & & 0.951 \\
Lowest quartile & 77.77 & 0.863 \\
Second quartile & 82.46 & 0.583 \\
Third quartile & 89.94 & 0.441 \\
Highest quartile & 96.04 & \\
\hline
\end{tabular}

Note: Table values represent averaged estimates from five imputed datasets.

${ }^{1}$ Based on (BYPARASP) How far in school the parent wants their tenth grader to go.

Categories 5, 6, and 7 (see descriptions below) were combined to produce these estimates.

$1=$ Less than high school graduation

$2=$ High school graduation or GED only

$3=$ Attend or complete 2 -year college/school

$4=$ Attend college, 4-year degree incomplete

$5=$ Graduate from college

$6=$ Obtain master's degree or equivalent

$7=$ Obtain $\mathrm{PhD}, \mathrm{MD}$, or other advanced degree

Regarding family rules, the majority of parents reported having rules for their child in terms of maintaining grades (82\%), doing homework (93\%), doing household chores $(88 \%)$, and watching television $(65 \%)$.

A quick comparison of the $95 \%$ confidence intervals (see table A-1) for each estimate in Table 3 a yields a number of other findings, including that the parents of students who received a high school diploma by 2006 (compared to GED recipients and non-completers) reported (1) slightly higher levels of involvement in their children's extracurricular activities, (2) higher levels of involvement in school functions, (3) slightly higher educational expectations for their children, and (4) slightly fewer instances of parent-school communication concerning children's school problems.

\section{Intercorrelations among Study Variables}

Table 4 presents estimates of the correlations between study variables. The two outcomes high school completion and postsecondary attendance by 2006 - had a moderate positive correlation $(r=.35, p<.01)$. Among the parental involvement variables, parent-school communication concerning children's school problems was negatively correlated with both high school completion 
$(r=-.19, p<.01)$ and postsecondary attendance $(r=-.24, p<.01)$. Parental aspirations for their children's postsecondary education was positively correlated with both high school completion $(r=$ $.13, p<.01)$ and postsecondary attendance $(r=.27, p<.01)$. The remaining parental involvement variables had weaker - although in some cases statistically significant - correlations with the two outcome variables. The student background variables (sex and SES) significantly correlated with a number of study variables. However, SES was more strongly correlated with postsecondary attendance $(r=.34, p<.01)$ than high school completion $(r=.19, p<.01)$. Regarding intercorrelations between the parental involvement variables, I found correlations similar to those reported in Fan and Williams (2010), and like their work, I observed these correlations to be no larger than .50, indicating minimal risk of multicollinearity.

Table 5 shows the weighted, non-imputed, percentage of spring 2002 tenth graders who ever attended a postsecondary institution (PSI), by high school completion status in 2006. Overall, 71\% of sophomores in 2002 had attended a PSI by 2006. However, a higher percentage of high school graduates $(77 \%)$ had attended a PSI, compared to GED recipients $(37 \%)$ and non-completers $(11 \%)$.

\section{Multivariate Analysis: High School Completion}

The logistic regression models analyzing the effects of parental involvement, sex, race/ethnicity, and SES were significant in predicting high school completion by 2006 (via diploma or GED) both for the 2002 sophomore cohort overall $(F(18,243.1)=32.58, p<.001)$ and for the subpopulation of non-diploma recipients $(F(18,246.3)=2.60, p<.001)$. Specifically, table 6 shows that parent participation in extracurricular activities with children $(\beta=.31, p=.02)$, parent participation in school functions $(\beta=.50, p=.03)$, and parents' aspirations for their children's postsecondary education $(\beta=.13, p<.001)$ demonstrated positive influences on high school completion among 2002 sophomores overall. Additionally, parent-school communication concerning child's school problems $(\beta=-.99, p<.001)$ and family rules for doing household chores $(\beta=-.40, p=.03)$ both exhibited negative effects. However, in the second model, after controlling for sex, race/ethnicity, and SES, none of the parental involvement variables significantly predicted GED completion among non-diploma recipients. 
Table 4

Intercorrelations among study variables

\begin{tabular}{|c|c|c|c|c|c|}
\hline Variable & 1 & 2 & 3 & 4 & 5 \\
\hline $\begin{array}{l}\text { 1. High school completion } \\
\text { by } 2006^{1} \\
\text { 2. Postsecondary attendance } \\
\text { by } 2006 \\
\text { 3. Parent participation in } \\
\text { extracurricular activities with } \\
\text { children }\end{array}$ & $0.35^{* *}$ & $0.13^{* *}$ & - & & \\
\hline $\begin{array}{l}\text { 4. Parental advising } \\
\text { 5. Parent-school } \\
\text { communication concerning }\end{array}$ & $0.06^{* *}$ & $0.10^{* *}$ & $0.44^{* *}$ & - & \\
\hline $\begin{array}{l}\text { children's school problems } \\
\text { 6. School-initiated contact }\end{array}$ & $-0.19 * *$ & $-0.24 * *$ & $-0.04 * *$ & $0.02 *$ & - \\
\hline $\begin{array}{l}\text { with parents } \\
\text { 7. Parent-initiated contact }\end{array}$ & 0.00 & 0.02 & $0.14 * *$ & $0.16^{* *}$ & $0.15^{* *}$ \\
\hline $\begin{array}{l}\text { with school } \\
\text { 8. Parent participation in }\end{array}$ & -0.01 & -0.01 & $0.19 * *$ & $0.25^{* *}$ & $0.35^{* *}$ \\
\hline $\begin{array}{l}\text { school functions } \\
\text { 9. Parental aspirations for } \\
\text { children's postsecondary }\end{array}$ & $0.09 * *$ & $0.18^{* *}$ & $0.33 * *$ & $0.24 * *$ & $-0.03 * *$ \\
\hline $\begin{array}{l}\text { education } \\
10 . \text { Family rules for }\end{array}$ & $0.13^{* *}$ & $0.27 * *$ & $0.11^{* *}$ & $0.19 * *$ & $-0.16^{* *}$ \\
\hline $\begin{array}{l}\text { maintaining grade } \\
\text { 11. Family rules for doing }\end{array}$ & 0.02 & 0.01 & $0.13^{* *}$ & $0.13^{* *}$ & $0.04 * *$ \\
\hline $\begin{array}{l}\text { homework } \\
\text { 12. Family rules for doing }\end{array}$ & 0.01 & 0.01 & $0.14 * *$ & $0.14 * *$ & 0.02 \\
\hline $\begin{array}{l}\text { household chores } \\
\text { 13. Family rules for watching }\end{array}$ & $-0.02 *$ & $-0.06 * *$ & $0.14^{* *}$ & $0.11^{* *}$ & $0.04 * *$ \\
\hline television & -0.01 & $-0.03 * *$ & $0.16^{* *}$ & $0.16^{* *}$ & $0.05^{* *}$ \\
\hline 14. Sex & $0.03 * *$ & $0.09 * *$ & -0.01 & 0.01 & $-0.13^{* *}$ \\
\hline 15. SES & $0.19 * *$ & $0.34 * *$ & $0.23^{* *}$ & $0.21 * *$ & $-0.06 * *$ \\
\hline
\end{tabular}

${ }^{*} \mathrm{p}<.05 ; * * \mathrm{p}<.01$

Note: Table values represent weighted, non-imputed data.

${ }^{1}$ Includes high school diploma recipients and GED recipients 
Table 4 (Cont'd)

Intercorrelations among study variables

\begin{tabular}{|c|c|c|c|c|c|}
\hline Variable & 6 & 7 & 8 & 9 & 10 \\
\hline $\begin{array}{l}\text { 1. High school completion } \\
\text { by } 2006^{1} \\
\text { 2. Postsecondary attendance } \\
\text { by } 2006 \\
\text { 3. Parent participation in } \\
\text { extracurricular activities with } \\
\text { children }\end{array}$ & & & & & \\
\hline $\begin{array}{l}\text { 4. Parental advising } \\
\text { 5. Parent-school } \\
\text { communication concerning } \\
\text { children's school problems } \\
\text { 6. School-initiated contact }\end{array}$ & & & & & \\
\hline $\begin{array}{l}\text { with parents } \\
\text { 7. Parent-initiated contact } \\
\text { with school }\end{array}$ & $0.47 *$ & - & & & \\
\hline $\begin{array}{l}\text { 8. Parent participation in } \\
\text { school functions } \\
\text { 9. Parental aspirations for } \\
\text { children's postsecondary }\end{array}$ & $0.24 * *$ & $0.27 * *$ & - & & \\
\hline $\begin{array}{l}\text { education } \\
10 . \text { Family rules for }\end{array}$ & $0.03^{* *}$ & 0.01 & $0.14^{* *}$ & - & \\
\hline $\begin{array}{l}\text { maintaining grade } \\
\text { 11. Family rules for doing }\end{array}$ & 0.01 & $0.06^{* *}$ & $0.05^{* *}$ & $0.06^{* *}$ & - \\
\hline $\begin{array}{l}\text { homework } \\
\text { 12. Family rules for doing }\end{array}$ & $0.04 * *$ & $0.06^{* *}$ & $0.07 * *$ & 0.01 & $0.44 * *$ \\
\hline $\begin{array}{l}\text { household chores } \\
\text { 13. Family rules for watching }\end{array}$ & $0.04 * *$ & $0.06^{* *}$ & $0.04 * *$ & -0.02 & $0.23 * *$ \\
\hline television & $0.06^{* *}$ & $0.10 * *$ & $0.11 * *$ & $0.03 * *$ & $0.24 * *$ \\
\hline 14. Sex & $-0.04 * *$ & $-0.04 * *$ & -0.01 & $0.06 * *$ & -0.02 \\
\hline 15. SES & $0.14^{* *}$ & $0.14^{* *}$ & $0.31 * *$ & $0.25 * *$ & $-0.03 *$ \\
\hline
\end{tabular}

${ }^{*} \mathrm{p}<.05 ; * * \mathrm{p}<.01$

Note: Table values represent weighted, non-imputed data.

${ }^{1}$ Includes high school diploma recipients and GED recipients 
Table 4 (Cont'd)

Intercorrelations among study variables

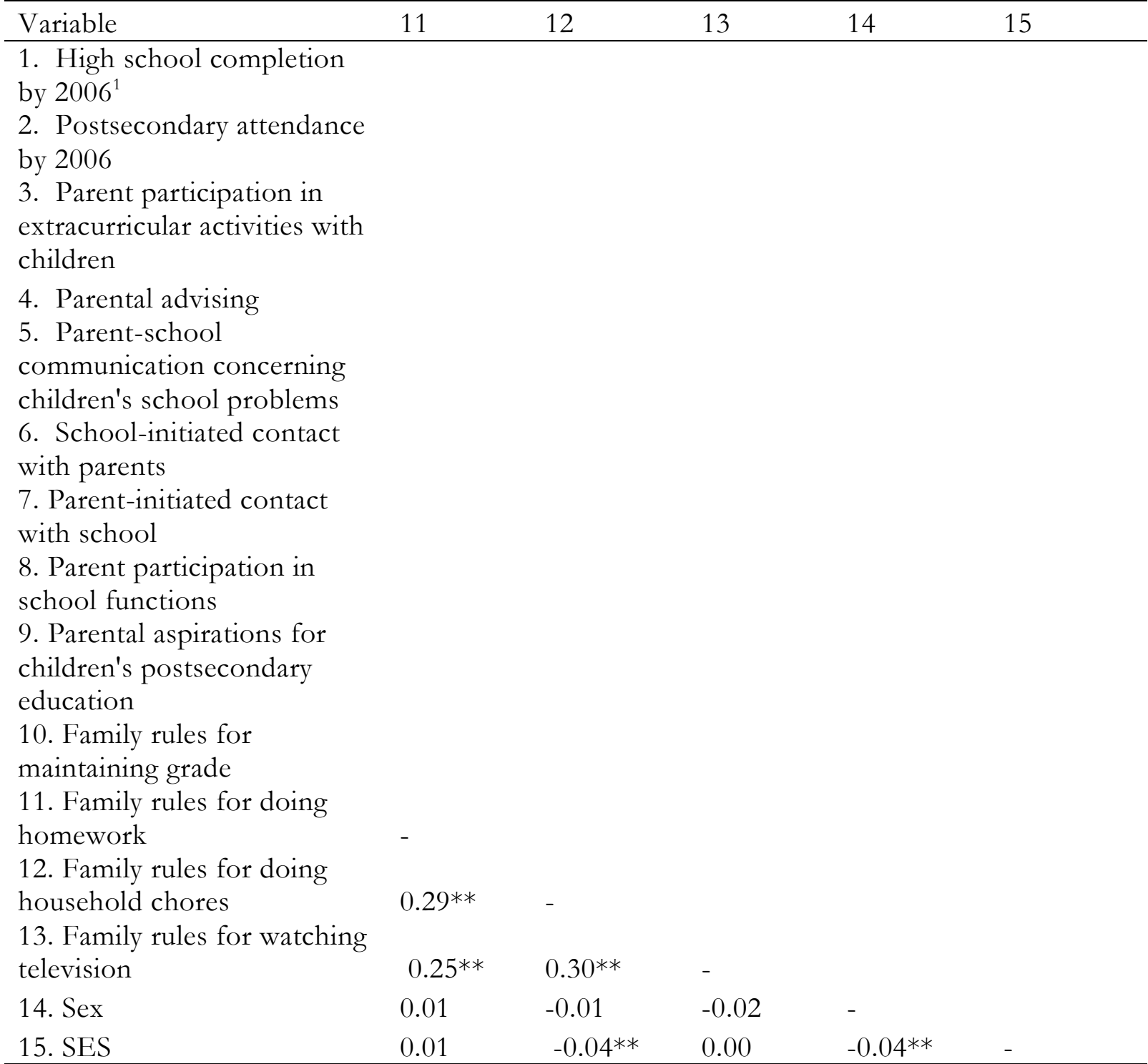

$*_{\mathrm{p}}<.05 ; * * \mathrm{p}<.01$

Note: Table values represent weighted, non-imputed data.

${ }^{1}$ Includes high school diploma recipients and GED recipients 
Table 5

Percentage of spring 2002 sophomores who ever attended a postsecondary institution, by high school completion status in 2006

\begin{tabular}{|c|c|c|c|c|c|c|c|}
\hline Total & & $\begin{array}{l}\text { High school } \\
\text { graduates }\end{array}$ & & GED recip & & Non-compl & $\mathrm{ers}^{1}$ \\
\hline Percentage & SE & Percentage & SE & Percentage & $\mathrm{SE}$ & Percentage & SE \\
\hline 70.9 & 0.67 & 77.3 & 0.58 & 37.3 & 2.71 & 10.7 & 1.27 \\
\hline
\end{tabular}

Note: Table values represent weighted, non-imputed data.

${ }^{1}$ Includes students receiving a certificate of attendance, and those still enrolled in high school in 2006.

Students receiving certificates of attendance and those still enrolled in high school in 2006 represent

approximately $1 \%$ of the unweighted study sample.

Table 6

Summary of logistic regression analyses for parental involvement variables predicting high school completion (via diploma or GED) by 2006, overall and among non-diploma recipients

\begin{tabular}{|c|c|c|c|c|}
\hline \multirow{2}{*}{$\begin{array}{l}\text { Variable } \\
\text { Parent participation in extracurricular activities with children }\end{array}$} & \multicolumn{2}{|c|}{ Overall $^{1}$} & \multicolumn{2}{|c|}{$\begin{array}{l}\text { Non-diploma } \\
\text { recipients }^{2}\end{array}$} \\
\hline & 0.31 & $*$ & 0.08 & \\
\hline Parental advising & 0.10 & & 0.21 & \\
\hline $\begin{array}{l}\text { Parent-school communication concerning children's school } \\
\text { problems }\end{array}$ & -0.99 & $* * *$ & -0.11 & \\
\hline School-initiated contact with parents & -0.10 & & -0.34 & \\
\hline Parent-initiated contact with school & 0.17 & & 0.27 & \\
\hline Parent participation in school functions & 0.50 & $*$ & -0.12 & \\
\hline Parental aspirations for children's postsecondary education & 0.13 & $* * *$ & 0.05 & \\
\hline Family rules for maintaining grade & 0.22 & & 0.11 & \\
\hline Family rules for doing homework & -0.11 & & -0.26 & \\
\hline Family rules for doing household chores & -0.40 & * & 0.20 & \\
\hline Family rules for watching television & -0.14 & & -0.26 & \\
\hline \multicolumn{5}{|l|}{ Sex } \\
\hline \multicolumn{5}{|l|}{ Male } \\
\hline Female & 0.17 & & -0.81 & \\
\hline \multicolumn{5}{|l|}{ Race/ethnicity } \\
\hline \multicolumn{5}{|l|}{ White } \\
\hline American Indian/Alaska Native & -0.82 & * & -0.13 & \\
\hline Asian/Pacific Islander & 0.19 & & -0.44 & \\
\hline Black & -0.50 & $* *$ & -0.50 & $*$ \\
\hline Hispanic & -0.48 & $* *$ & -0.60 & $*$ \\
\hline Two or more races & -0.32 & & -0.01 & \\
\hline SES & 0.88 & $* * *$ & 0.56 & $* * *$ \\
\hline
\end{tabular}

${ }^{*} \mathrm{p}<.05 ; * * \mathrm{p}<.01 ; * * * \mathrm{p}<.001$

Note: Table values (standardized regression coefficients) represent averaged estimates from five imputed datasets. Italics refer to reference categories. 
${ }^{1}$ Among the entire cohort of tenth graders in 2002.

${ }^{2}$ Among students who did not earn a high school diploma by 2006 (includes GED recipients, students receiving certificates of attendance, and students still enrolled in high school in 2006). Students receiving certificates of attendance and those still enrolled in high school in 2006 represent approximately $1 \%$ of the unweighted study sample.

Table 7

Summary of logistic regression analyses for parental involvement variables predicting postsecondary attendance by 2006, overall and among non-diploma recipients

\begin{tabular}{|c|c|c|c|c|}
\hline Variable & \multicolumn{2}{|l|}{ Overall $^{1}$} & \multicolumn{2}{|c|}{$\begin{array}{l}\text { Non-diploma } \\
\text { recipients }^{2}\end{array}$} \\
\hline $\begin{array}{l}\text { Parent participation in extracurricular activities with } \\
\text { children }\end{array}$ & 0.14 & & 0.00 & \\
\hline Parental advising & 0.09 & & 0.15 & \\
\hline $\begin{array}{l}\text { Parent-school communication concerning children's school } \\
\text { problems }\end{array}$ & -0.92 & $* * *$ & -0.37 & $*$ \\
\hline School-initiated contact with parents & -0.06 & & -0.16 & \\
\hline Parent-initiated contact with school & 0.03 & & 0.06 & \\
\hline Parent participation in school functions & 0.79 & $* * *$ & 0.95 & $*$ \\
\hline Parental aspirations for children's postsecondary education & 0.28 & $* * *$ & -0.01 & \\
\hline Family rules for maintaining grade & 0.06 & & 0.18 & \\
\hline Family rules for doing homework & 0.14 & & 0.02 & \\
\hline Family rules for doing household chores & -0.41 & $* *$ & -0.44 & \\
\hline Family rules for watching television & -0.23 & $* *$ & -0.08 & \\
\hline \multicolumn{5}{|l|}{ Sex } \\
\hline \multicolumn{5}{|l|}{ Male } \\
\hline Female & 0.36 & $* * *$ & -0.06 & \\
\hline \multicolumn{5}{|l|}{ Race/ethnicity } \\
\hline \multicolumn{5}{|l|}{ White } \\
\hline American Indian/Alaska Native & -0.68 & * & -0.51 & \\
\hline Asian/Pacific Islander & 0.62 & $* * *$ & 0.16 & \\
\hline Black & -0.18 & $*$ & 0.08 & \\
\hline Hispanic & -0.10 & & 0.10 & \\
\hline Two or more races & -0.35 & * & 0.16 & \\
\hline SES & 1.01 & $* * *$ & 0.77 & $* * *$ \\
\hline
\end{tabular}

${ }^{*} \mathrm{p}<.05 ;{ }^{* *} \mathrm{p}<.01 ; * * * \mathrm{p}<.001$

Note: Table values (standardized regression coefficients) represent averaged estimates from five imputed datasets. Italics refer to reference categories.

${ }^{1}$ Among the entire cohort of tenth graders in 2002.

${ }^{2}$ Among students who did not earn a high school diploma by 2006 (includes GED recipients, students receiving certificates of attendance, and students still enrolled in high school in 2006). Students receiving certificates of attendance and those still enrolled in high school in 2006 represent approximately $1 \%$ of the unweighted study sample. 


\section{Multivariate Analysis: Postsecondary Attendance}

The logistic regression models analyzing the effects of parental involvement, sex, race/ethnicity, and SES were also significant in predicting postsecondary attendance by 2006 both for the 2002 sophomore cohort overall $(F(18,306.0)=66.14, p<.001)$ and for the subpopulation of non-diploma recipients $(F(18,249.7)=3.00, p<.001)$. Similar to the high school completion model, parent participation in school functions $(\beta=.79, p<.001)$, and parents' aspirations for their children's postsecondary education $(\beta=.28, p<.001)$ positively influenced postsecondary attendance among 2002 sophomores overall (see table 7). However, parent participation in extracurricular activities with children $(\beta=.14, p=.07)$, was not a significant predictor. Also, among study variables, there were more statistically significant negative predictors of postsecondary attendance than for high school completion. Specifically, parent-school communication concerning children's school problems $(\beta=-.92, p<.001)$ and family rules for doing household chores $(\beta=$ - $41, p<.01)$ continued to show negative effects and another variable - family rules for watching television - also demonstrated a negative influence on postsecondary attendance for the cohort overall $(\beta=-.23, p<.01)$. Among non-diploma recipients, the only significant positive predictor of postsecondary attendance (other than SES) was parent participation in school functions $(\beta=.95, p$ $=.01)$. The only significant negative predictor was parent-school communication concerning children's school problems $(\beta=-.37, p=.01)$.

\section{Discussion}

In this study, I replicate the means and intercorrelations reported by Fan \& Williams (2010) who also employed multiple imputation (mi) techniques to address missing data across the same ELS parental involvement, sex, and SES variables as used here. In their study, parental involvement was used to predict students' academic self-efficacy, engagement, and intrinsic motivation in English and mathematics. Although the Fan and Williams study used the MI Markov Chain Monte Carlo approach (available through the PROC MI command in the SAS 9.2 software package) and their analysis generated only three mi datasets (compared to the five mi datasets generated here), my results are similar to theirs for each of these variables (although Fan and Williams appear to have reported standard deviations, which differ from my weighted estimates of standard error).

The current study further extends the literature by examining how different aspects of parental involvement influence other educational outcomes, namely, high school completion and postsecondary attendance. The findings I report here suggest that explanations for student persistence through secondary school and on to college that depend solely on race, ethnicity, socioeconomic status, or other background characteristics are incomplete and miss other important factors (such as parental involvement) that also contribute to these outcomes. Similar to studies that examined the relationship between parental involvement dimensions and other outcomes - such as middle school dropout behavior (Rumberger, 1995) and students' self-efficacy and engagement in mathematics and English (Fan \& Williams, 2010) - it appears that parents' educational expectations for their children also play a significant role in whether students from all backgrounds persist toward completion of high school and whether they attend a postsecondary institution. In terms of high school completion (by 2006) among the entire cohort of 2002 sophomores, in this study I also found parent participation in extracurricular activities and school functions to be significant positive predictors, while communication between parent and school about children's school problems and having family rules for doing household chores exhibited negative effects. With regards to 
postsecondary attendance, parent participation in school functions was a positive predictor of overall cohort attendance at a PSI as well as separately among non-high school diploma recipients.

The only negative predictor shared between the overall cohort model and the non-diploma recipients model was parent-school communication about children's school problems. This finding is similar to the results reported by Fan (2001) when exploring a similar type of involvement among parents of high school-aged students. This specific parental involvement dimension, termed "Contact with School", was comprised of three survey items regarding parents' contact with their children's school about (1) academic performance, (2) academic programs, and (3) behavior. Fan observed that the students of parents who reported more frequent contact with the school also had lower initial academic performance, which may explain the negative relationship between parentschool contact and academic growth, as measured in Fan's study. Thus, it is not surprising that parent-school communication about children's school problems is significantly related to dropping out of high school and not enrolling in postsecondary education.

While I am not recommending that parents and schools avoid communicating about students' academic or behavior problems, consideration should be given to increasing the frequency of other kinds of parent-school communication and contact. Unfortunately, parents often face time pressures and competing demands for their attention, leading to families and schools only communicating when there is a problem. Over time, a pattern of negative interactions (and disagreements) between parents and schools develops (Epstein, 1996), which is counterproductive to the goal of increasing positive family-school engagement. For this, and possibly other reasons, teachers of adolescents should plan for earlier engagement with parents (i.e., before problems surface) using efficient and effective communication tools, such as email, Web sites, electronic discussion boards, and blogs, to reduce or eliminate this barrier (Mandara, 2009).

An explanation for the lack of significant associations in the non-diploma recipients model for high school completion (via GED) is not easily found. One consideration is that possibly other factors, not studied here, are influential in predicting GED completion among students who did not earn a high school diploma by 2006. For instance, in another analysis of GED recipients from this ELS cohort, Malkus and Sen (2012) found that when asked about their reasons for leaving high school, a higher percentage of GED recipients reported leaving for a school-related reason (91\%) than either a work-related or family-related reason (29\% and $26 \%$, respectively). Among GED recipients, the highest reported school-related reasons for leaving high school were: leavers thought it would be easier to get a GED (48\%), leavers did not like school (44\%), leavers were getting poor grades or failing school (39\%), or leavers had missed too many school days $(39 \%)$. As to reasons for earning a GED, $66 \%$ of recipients cited a need to meet requirements for additional study (e.g., a two- or four-year degree or sub-baccalaureate credential).

These findings could inform future studies of influential predictors of high school dropout and GED completion. That is, students at risk of dropping out of school and not completing any secondary or postsecondary credential may benefit from parental involvement in their high school education and extracurricular activities but perhaps they would benefit even more from school interventions designed to address some of the most frequently reported reasons for dropping out. Take for example, research demonstrating the strong negative relationship between chronic absenteeism and students' academic achievement, high school graduation and post-secondary enrollment outcomes (Balfanz \& Byrnes, 2012). To address this problem, state and local education agencies have begun to add measures of student attendance to "early warning" indicator systems used to identify students at risk of dropping out or falling behind in school. The extent to which these early warning systems and interventions could explicitly include ways to engage parents - and 
then study the effects on high school completion - is a promising area for future research and policy development.

The finding that parental involvement in school functions positively predicts postsecondary attendance among GED recipients could be used to encourage continued parental engagement for high school dropouts who enroll in a GED program. Furthermore, although the percentage of GED recipients who attended a postsecondary institution by $2006(37 \%)$ is lower than for high school graduates, the fact that more than a third went on to enroll in some type of postsecondary education should encourage policymakers and practitioners to target resources and support for more of these students to pursue higher education. In fact, evidence of successful programs that help students earn a GED credential and enroll in college are beginning to emerge. For example, a study of the Bridge to Health and Business program, which offers students a career-related GED curriculum, found that one year after enrolling in the program, Bridge students were much more likely than those pursuing traditional GED programs to have finished the course, passed the GED exam, and enrolled in college (Martin \& Broadus, 2013). Future research should also study the postsecondary experiences of GED recipients in the ELS cohort to describe the range of options high school dropouts take advantage of and to what extent parental involvement may play a role in their success (or lack thereof).

\section{Conclusion: Parental Involvement Matters in High School}

The results presented here underscore the continued need for parental involvement once children reach high school. How to encourage and sustain effective levels of parental engagement is hard to prescribe, but the literature offers recommendations for parents, the federal government, and state and local educational agencies. For parents, the strategies that worked with their children in elementary school may not be as effective once the children reach adolescence. Therefore, research suggests that parents engage in more developmentally appropriate ways, such as communicating high expectations for their children's future (Chao \& Hill, 2009). While, the current study and previous research overwhelmingly support the idea that parental expectations play a major role in a whole host of educational outcomes for children, this study also shows where high expectations, alone, may not be enough to propel students to reach their potential. That is, although I show here that (with the exception of Asian/Pacific Islanders), the parents of black students reported having the highest educational aspirations for their children in tenth-grade, being black was also associated with lower likelihoods of high school completion and postsecondary attendance, even after controlling for SES (see tables 6 and 7). To improve students' chances of success, research suggests that parents supplement their high expectations with actively assisting their children in planning for college (Chao \& Hill, 2009). To the extent that parents are not familiar with the college planning process, schools should be working to provide this information and other skills to enhance the "college knowledge" of both parents and students. Other recommendations include augmenting the instruction and extracurricular activities that youth receive at school by enrolling them in afterschool tutorials, study groups, community sports programs, etc. However, given that high SES parents will likely have better access to these kinds of services than low SES parents, federal and locally-funded programs may be needed to offset costs, as well as provide transportation and other resources for high-needs children. Finally, research suggests that parental involvement in such activities as managing the homework of high school-aged children should shift from a supervisory role to more of a supportive one, as these youth become increasingly more independent and able to make decisions for themselves (Chao \& Hill, 2009). However, learning to do this effectively takes skill, specifically in terms of knowing how to provide opportunities for youth to link schoolwork with 
current events, how to monitor (rather than check) homework, and how to provide the autonomy for high school students to make decisions, while still setting boundaries around time use. This is another area where schools have a duty to coach and train parents about effectively engaging in their children's education.

As mentioned earlier, NCLB (and now ESSA) provided funding (through Title I) for parent engagement activities and required that schools provide parents with a written parental involvement policy that is based on parent input and leadership. The law also required that these policies be accessible to parents with limited English proficiency and that other reasonable support be provided (for more information, see section 1118 of NCLB or section 1116 of ESSA). However, these requirements are of little use if they are not informed by the local context. That is, one-size-fits-all approaches to increasing parental involvement will not work in all communities. To be effective for black and Latino parents and students, for example, some research suggests that school leaders first cultivate a school climate that welcomes and includes cultural diversity so that trust is established between parents, students, teachers, principals, and community members (Epstein \& Sanders, 2002; Henderson \& Mapp, 2002). In other words, for schools to succeed in engaging families from diverse backgrounds, more consideration must be given to practices that recognize, respect, and address the needs of individual families (as well as class and cultural differences between families), and that embrace a philosophy of partnership with shared responsibility and power.

\section{Limitations}

Most of the data used in this analysis were self-reported by students and their parents and, while typical of large-scale studies, this method of data collection can yield biased estimates due to participants providing socially-desirable or unreliable information. Furthermore, no causal conclusions can be made from the multivariate statistics presented here. Although I observed statistically significant associations between some aspects of parental involvement in 2002 and students' high school completion and postsecondary attendance by 2006 , there are potentially other factors not studied which may have also influenced these outcomes. For instance, parents' aspirations for their children's educational attainment appears to have a strong influence on students' high school completion and postsecondary attendance (as well as on other educational outcomes, as shown in previous studies). However, this relationship is not in itself evidence that simply having high educational expectations for one's child, regardless of relevant student characteristics (e.g., prior achievement or behavior), will lead to favorable outcomes for him/her. It may be that student achievement or behavior in earlier grades may influence parents' educational expectations for their children in tenth grade. Future research should study parental expectations for tenth grade students across various student characteristics prior to tenth grade (e.g., ninth grade GPA, whether student had ever been held back a grade or suspended from school) and examine the possible mediating effects of these prior characteristics on the relationship between parents' educational aspirations for their children and students' high school completion and postsecondary enrollment. Finally, I found both positive and negative relationships between specific types of parental involvement and the educational outcomes studied here (high school completion and postsecondary attendance). The extent to which this narrow set of activities and behaviors accurately captures the most important aspects of parental involvement poses limitations for the study of this construct. Thus, the analysis presented here may underestimate the real contributions that parents make to their children's growth, development, and success during and after the high school years. 


\section{References}

107 ${ }^{\text {th }}$ Congress. (2002).Pub. L. No. 107-110, 114 Stat. 1425 No Child Left Behind Act of 2001. Retrieved from https://www.gpo.gov/fdsys/pkg/PLAW-107publ110/html/PLAW107publ110.htm

$114^{\text {th }}$ Congress. (2015). Every Student Succeeds Act. Pub. L. No. 114-95. Retrieved from https://www.gpo.gov/fdsys/pkg/BILLS-114s1177enr/pdf/BILLS-114s1177enr.pdf

Alexander, K. L., Entwisle, D. R., \& Horsey, C. S. (1997). From first grade forward: Early foundations of high school dropout. Sociology of Education, (70)2, 87-107. http://dx.doi.org/10.2307/2673158

American Council on Education. (2008). 2008 GED Testing Program Statistical Report. Washington, DC: Author. Retrieved from http://www.gedtestingservice.com/uploads/files/9d42c6660ec6184f73f466f2c53ef279.5MB

Aston, N. M., \& McLanahan, S. S. (1991). Family structure, parental practices and high school completion. American Sociological Review, 56, 309-320. http://dx.doi.org/10.2307/2096106

Balfanz, R. \& Byrnes, V. (2012). Chronic Absenteeism: Summarizing What We Know From Nationally Available Data. Baltimore: Johns Hopkins University Center for Social Organization of Schools.

Baraldi, A. N., \& Enders, C. K. (2010). An introduction to modern missing data analyses. Journal of School Psychology, 48, 5-37. http://dx.doi.org/10.1016/i.jsp.2009.10.001

Battin-Pearson, S., Newcomb, M. D., Abbott, R. D., Hill, K. G., Catalano, R. F., \& Hawkins, J. D. (2000). Predictors of early high school dropout: A test of five theories. Journal of Educational Psychology, (92)3, 568-582. http://dx.doi.org/10.1037/0022-0663.92.3.568

Baum, S., Ma, J., \& Payea, K. (2013). Education pays 2013: The benefits of higher education for individuals and society. New York: The College Board.

Brand, J. E., \& Xie, Y. (2010). Who benefits most from college? Evidence for negative selection in heterogeneous economic returns to higher education. American Sociological Review, 75(2) 273302. http://dx.doi.org/10.1177/0003122410363567

Bureau of Labor Statistics (nd). Labor Force Statistics from the Current Population Survey. Retrieved from: http://www.bls.gov/cps/earnings.htm\#education.

Chao, R. K., \& Hill, N. E. (2009). Recommendations for developmentally appropriate strategies for parental involvement during adolescence. In N. E. Hill \& R. K. Chao, Families, schools, and the adolescent: Connecting research, policy, and practice. New York: Teachers College Press.

deCastro, B. S., \& Catsambis, S. (2009). Parents still matter: Parental links to the behaviors and future outlook of high school seniors. In N. E. Hill \& R. K. Chao, Families, schools, and the adolescent: Connecting research, policy, and practice. New York: Teachers College Press.

Desimone, L. (1999). Linking parent involvement with student achievement: Do race and income matter? Journal of Educational Research, 93(1), 11-30. http://dx.doi.org/10.1080/00220679909597625

Domina, T. (2005). Leveling the home advantage: Assessing the effectiveness of parental involvement in elementary school. Sociology of Education, (78), 233-249. http://dx.doi.org/10.1177/003804070507800303

Dynarski, M., \& Gleason, P. (1999). How can we help? Lessons from federal drop-out prevention programs. Policy brief. Princeton, NJ: Mathematica Policy Research, Inc. Retrieved from www.mathematica-mpr.com/publications/PDFs/howhelp.pdf.

Eccles, J. S., Midgley, C., Wigfield., A., Buchanan, C. M., Reuman, D., Flanagan, C., \& MacIver, D. (1993). Development during adolescence: The impact of stage-environment fit on young 
adolescents' experiences in schools and families. American Psychologist, 48 (2), 90-101. http://dx.doi.org/10.1037/0003-066X.48.2.90

Epstein, J. L., \& Dauber, S. L. (1991). School programs and teacher practices of parent involvement in inner-city elementary and middle schools. Elementary School Journal, 91:289-305. http://dx.doi.org/10.1086/461656

Epstein, J. L. (1995). School/Family/Community partnerships: Caring for the children we share. The Phi Delta Kappan, (76)9, 701-712.

Epstein, J. L., \& Sanders, M. G. (2002). Family, school, and community partnerships. In M. H. Bornstein (Ed.), Handbook of parenting: Vol. 5. Practical issues in parenting (2 ${ }^{\text {nd }}$ ed., pp. 407-437). Mahwah, NJ: Erlbaum.

Fan, X. (2001). Parental involvement and students' academic achievement: A Growth modeling analysis. The Journal of Experimental Education, (70)1, 27-61. http://dx.doi.org/10.1080/00220970109599497

Fan, W., \& Williams, C. M. (2010). The effects of parental involvement on students' academic selfefficacy, engagement and intrinsic motivation. Educational Psychology, (30)1, 53-74. http://dx.doi.org/10.1080/01443410903353302

Fan, W., \& Wolters, C. A. (2014). School motivation and high school dropout: The mediating role of educational expectation. British Journal of Educational Psychology, (84), 22-39. http://dx.doi.org/10.1111/bjep.12002

Fichman, M., \& Cummings, J. N. (2003). Multiple imputation for missing data: Making the most of what you know. Organizational Research Methods, (6)3, 282-308. http://dx.doi.org/10.1177/1094428103255532

Fishel, M., \& Ramirez, L. (2005). Evidence-based parent involvement interventions with schoolaged children. School Psychology Quarterly, (20)4, 371-402. http://dx.doi.org/10.1521/scpq.2005.20.4.371

Gonzalez-DeHass, A. R., Willems, P. P., \& Doan Holbein, M. F. (2005). Examining the relationship between parental involvement and student motivation. Educational Psychology Review, (17)2, 99123. http://dx.doi.org/10.1007/s10648-005-3949-7

Graham, J.W., \& Hofer, S.M. (2000). Multiple imputation in multivariate research. In T.D. Little, K.U. Schnable, \& J. Baumert (Eds.), Modeling longitudinal and multilevel data: Practical issues, applied approaches, and specific examples (pp. 201-218). Mahwah, NJ:Erlbaum.

Grolnick, W. S., \& Slowiaczek, M. L. (1994). Parents' involvement in children's schooling: A Multidimensional conceptualization and motivational model. Child Development, (65), 237-252. http://dx.doi.org/10.2307/1131378

Heckman, J. J., Humphries, J. E., \& Mader, N. S. (2010). The GED (NBER Working Paper 16064). Cambridge, MA: National Bureau of Economic Research. Retrieved from: http://www.nber.org/papers/w16064.

Henderson, A. T., \& Mapp, K. L. (2002). The Impact of School, Family, and Community Connections on Student Achievement. Austin, TX: Southwest Educational Development Laboratory. Retrieved from: https://www.sedl.org/connections/resources/evidence.pdf.

Henry, K. L., Knight, K. E., \& Thornberry, T. P. (2012). School disengagement as a predictor of dropout, delinquency, and problem substance use during adolescence and early adulthood. Journal of Youth and Adolescence, (41), 156-166. http://dx.doi.org/10.1007/s10964-011-9665-3

Hill, N. E., \& Craft, S. A. (2003). Parent-school involvement and school performance: Mediated pathways among socioeconomically comparable African American and Euro-American families. Journal of Educational Psychology, (95)1, 74-83. http://dx.doi.org/10.1037/0022$\underline{0663.95 .1 .74}$ 
Hill, N. E., Castellino, D. R., Lansford, J. E., Nowlin, P., Dodge, K. A., Bates, J., \& Pettit, G. (2004). Parent-academic involvement as related to school behavior, achievement, and aspirations: Demographic variations across adolescence. Child Development, 75(4), 1491-1509. http://dx.doi.org/10.1111/i.1467-8624.2004.00753.x

Hill, N. E., \& Chao, R. K. (2009). Families, schools, and the adolescent: Connecting research, policy, and practice. New York: Teachers College Press.

Hill, N. E., Tyson, D. F., \& Bromell, L. (2009). Developmentally appropriate strategies across ethnicity and socioeconomic status: Parental involvement during middle school. In N. E. Hill \& R. K. Chao, Families, schools, and the adolescent: Connecting research, policy, and practice. New York: Teachers College Press.

Hoover-Dempsey, K. V., Ice, C. L., \& Whitaker, M. C. (2009). "We're way past reading together" Why and how parental involvement in adolescence makes sense. In N. E. Hill \& R. K. Chao, Families, schools, and the adolescent: Connecting research, policy, and practice. New York: Teachers College Press.

Howell, D. C. (2007). The analysis of missing data. In Outhwaite, W. \& Turner, S. Handbook of Social Science Methodology. London: Sage. http://dx.doi.org/10.4135/9781848607958.n11

Ingels, S. J., Pratt, D. J., Rogers, J. E., Siegel, P. H., \& Stutts, E. S. (2004). Education Longitudinal Study of 2002: Base Year Data File User's Manual (NCES 2004-405). U.S. Department of Education. Washington, DC: National Center for Education Statistics.

Ingels, S.J., Burns, L.J., Chen, X., Cataldi, E.F., \& Charleston, S. (2005). A Profile of the American High School Sophomore in 2002: Initial Results from the Base Year of the Education Longitudinal Study of 2002 (NCES 2005-338). U.S. Department of Education, Washington, DC: National Center for Education Statistics.

Ingels, S.J., Pratt, D.J, Alexander, C.P., Jewell, D.M., Lauff, E. Mattox, T.L., and Wilson, D. (2014). Education Longitudinal Study of 2002 Third Follow-up Data File Documentation (NCES 2014-364). National Center for Education Statistics, Institute of Education Sciences, U.S. Department of Education. Washington, DC. Retrieved [date] from http://nces.ed.gov/pubsearch.

Izzo, C. V., Weissberg, R. P., Kasprow, W. J., \& Fendrich, M. (1999). A Longitudinal assessment of teacher perceptions of parent involvement in children's education and school performance. American Journal of Community Psychology, (27)6, 817- 839. http://dx.doi.org/10.1023/A:1022262625984

Jeynes, W. H. (2005). A meta-analysis of the relation of parental involvement to urban elementary school student academic achievement. Urban Education, 40, 237-269. http://dx.doi.org/10.1177/0042085905274540

Kena, G., Musu-Gillette, L., Robinson, J., Wang, X., Rathbun, A., Zhang, J., Wilkinson-Flicker, S., Barmer, A., and Dunlop Velez, E. (2015). The Condition of Education 2015 (NCES 2015-144). U.S. Department of Education, National Center for Education Statistics. Washington, DC. Retrieved [date] from http://nces.ed.gov/pubsearch.

Kenkel, D. S. (1991). Health behavior, health knowledge, and schooling. Journal of Political Economy, (99)2, 287-305. http://dx.doi.org/10.1086/261751

Lauff, E., \& Ingels, S. J. (2013). Education Longitudinal Study of 2002 (ELS: 2002): A First look at 2002 bigh school sophomores 10 years later (NCES 2014-363). U.S. Department of Education. Washington, DC: National Center for Education Statistics.

Little, R.J.A. \& Rubin, D.B. (1987). Statistical analysis with missing data. New York, Wiley.

Mandara, J. (2009). Reaching out to all families: Developing parental involvement workshops for African American parents of middle school students. In N. E. Hill \& R. K. Chao, Families, 
schools, and the adolescent: Connecting research, policy, and practice. New York: Teachers College Press.

Malkus, N., \& Sen, A. (2012). Characteristics of GED recipients in high school: 2002-06. (NCES 2012-025). U.S. Department of Education. Washington, DC: National Center for Education Statistics.

Martin, V., \& Broadus, J. (2013). Enhancing GED instruction to prepare students for college and careers: Early success in LaGuardia Community College's Bridge to Health and Business program. Policy brief. New York, NY: MDRC. http://dx.doi.org/10.2139/ssrn.2265891

National Dropout Prevention Center/Network. (n.d.). Effective Strategies. Retrieved from http://dropoutprevention.org/effective-strategies/

Neild, R. C., Stoner-Eby, S., \& Furstenberg, F. (2008). Connecting entrance and departure: The transition to ninth grade and high school dropout. Education and Urban Society, (40)5, 543-569. http://dx.doi.org/10.1177/0013124508316438

Nicolau, S., \& Ramos, C. L. (1990). Together is better: Building strong relationships between school and Hispanic parents. Washington, D.C: Hispanic Policy Development Project.

Olivos, E. M. (2006). The power of parents: A critical perspective of bicultural parent involvement in public schools. New York: Peter Lang.

Ou, S. (2008). Do GED recipients differ from graduates and school dropouts? Findings from an inner-city cohort. Urban Education, 43(1), 83-117. http://dx.doi.org/10.1177/0042085907305187

Patterson, M. B., Song, W., Zhang, J. (2009). GED candidates and their postsecondary educational outcomes: A Pilot study. Research Studies 2009-5, GED Testing Service, Washington, DC. Retrieved from: http://www.gedtestingservice.com/uploads/files/e248d9c38a9dc05883770deecab2261a.pdf

Pew Research Center. (2014). The rising cost of not going to college. Retrieved from http://www.pewsocialtrends.org/2014/02/11/the-rising-cost-of-not-going-to-college/

Powell-Smith, K. A., Stoner, G., Shinn, M. R., \& Good III, R. H. (2000). Parent tutoring in reading using literature and curriculum materials: Impact on student reading achievement. School Psychology Review, (29)1, 5-27.

Raghunathan, T.E., Lepkowski, J.M., Van Hoewyk, J., and Solenberger, P. (2001). A Multivariate technique for multiply imputing missing values using a sequence of regression models. Survey Methodology, 27 (1), 85-95.

Ross, T., Kena, G., Rathbun, A., KewalRamani, A., Zhang, J., Kristapovich, P., and Manning, E. (2012). Higher Education: Gaps in Access and Persistence Study (NCES 2012-046). U.S. Department of Education, National Center for Education Statistics. Washington, DC: Government Printing Office.

Rubin (1987). Multiple imputation for nonresponse in surveys. New York: Wiley. http://dx.doi.org/10.1002/9780470316696

Rumberger. R. W. (1995). Dropping out of middle school: A Multilevel analysis of students and schools. American Educational Research Journal, (32), 583-625. http://dx.doi.org/10.3102/00028312032003583

Rumberger, R. W., \& Larson, K. A. (1998). Student mobility and the increased risk of high school dropout. American Journal of Education, (107), 1-35. http://dx.doi.org/10.1086/444201

Sheldon, S. J., \& Epstein, J. L. (2005). Involvement Counts: Family and community partnerships and mathematics achievement. The Journal of Educational Research, (98)4, 196-206. http://dx.doi.org/10.3200/JOER.98.4.196-207 
Simon, B. S. (2000). Predictors of high school and family partnerships and the influence of partnerships on student success. Unpublished doctoral dissertation. Johns Hopkins University. Baltimore MD. http://dx.doi.org/10.1177/019263650108562702

Simon, B. S. (2001). Family involvement in high school: Predictors and effects. NASSP Bulletin, (85)627, 8-19.

Singh, K., Bickley, P. G., Trivette, P., \& Keith, T. Z. (1995). The Effects of four components of parental involvement on eighth-grade student achievement: Structural analysis of NELS-88 data. School Psychology Review, (24)2, 299-317.

Sirvani, H. (2007). The effect of teacher communication with parents on students' mathematics achievement. American Secondary Education, (36)1, 31-46.

Smith, S., Robbins, T., Stagman, S. \& Mahur, D. (2013). Parent engagement from preschool through grade 3: A guide for policymakers. Report. New York: National Center for Children in Poverty.

Spera, C. (2005). A review of the relationship among parenting practices, parenting styles, and adolescent school achievement. Educational Psychology Review, 17(2), 125-146. http://dx.doi.org/10.1007/s10648-005-3950-1

StataCorp. (2013). Stata Statistical Software: Release 13. College Station, TX: Author.

Sui-Chu, E. H., \& Willms, J. D. (1996). Effects of parental involvement on eighth-grade achievement. Sociology of Education, (69) 126-141. http://dx.doi.org/10.2307/2112802

U.S. Department of Education, National Center for Education Statistics (1998). Factors associated with father's and mother's involvement in their children's schools. Washington, D.C.: Author.

Yan, W., \& Lin, Q. (2005). Parent involvement and mathematics achievement: Contrast across racial and ethnic groups. Journal of Educational Research, (99)2, 116-127. http://dx.doi.org/10.3200/JOER.99.2.116

Zellman, G., \& Waterman, J. (1998). Understanding the impact of parent school involvement on children's educational outcomes. Journal of Educational Research, (91)6, 370-380. http://dx.doi.org/10.1080/00220679809597566 


\section{Appendix A}

Table A-1.

95\% confidence intervals for mean estimates of parental involvement variables, by high school completion status in 2006

\begin{tabular}{|c|c|c|c|c|}
\hline & Total & $\begin{array}{l}\text { High School } \\
\text { Diploma } \\
\text { Recipients }\end{array}$ & $\begin{array}{l}\text { GED } \\
\text { recipients }\end{array}$ & $\begin{array}{l}\text { Non- }^{-} \\
\text {completers }^{1}\end{array}$ \\
\hline Parental Involvement Variable & {$[95 \% \mathrm{CI}]$} & {$[95 \% \mathrm{CI}$} & {$[95 \% \mathrm{CI}]$} & {$[95 \% \mathrm{CI}]$} \\
\hline $\begin{array}{l}\text { Parent participation in } \\
\text { extracurricular activities with } \\
\text { children }\end{array}$ & $\begin{array}{l}{[3.04} \\
3.07] \\
{[2.26}\end{array}$ & {$[3.07,3.10]$} & {$[2.87,3.01]$} & {$[2.79,2.90]$} \\
\hline Parental advising & $2.28]$ & {$[2.27,2.30]$} & {$[2.18,2.31]$} & {$[2.10,2.21]$} \\
\hline $\begin{array}{l}\text { Parent-school communication } \\
\text { concerning children's school } \\
\text { problems }\end{array}$ & $\begin{array}{l}{[1.31} \\
1.34]\end{array}$ & {$[1.25,1.27]$} & {$[1.64,1.88]$} & {$[1.72,1.88]$} \\
\hline $\begin{array}{l}\text { School-initiated contact with } \\
\text { parents }\end{array}$ & $\begin{array}{l}{[1.32} \\
1.34]\end{array}$ & {$[1.31,1.34]$} & {$[1.27,1.40]$} & {$[1.33,1.43]$} \\
\hline $\begin{array}{l}\text { Parent-initiated contact with } \\
\text { school }\end{array}$ & $\begin{array}{l}{[1.36} \\
1.38]\end{array}$ & {$[1.35,1.37]$} & {$[1.43,1.57]$} & {$[1.37,1.49]$} \\
\hline $\begin{array}{l}\text { Parent participation in school } \\
\text { functions }\end{array}$ & $\begin{array}{l}{[0.28} \\
0.30]\end{array}$ & {$[0.29,0.31]$} & {$[0.18,0.24]$} & {$[0.16,0.21]$} \\
\hline $\begin{array}{l}\text { Parental aspirations for } \\
\text { children's postsecondary } \\
\text { education }\end{array}$ & $\begin{array}{l}{[5.29} \\
5.35]\end{array}$ & {$[5.35,5.41]$} & {$[4.82,5.11]$} & {$[4.71,4.95]$} \\
\hline $\begin{array}{l}\text { Family rules for maintaining } \\
\text { grade }\end{array}$ & $\begin{array}{l}{[0.81} \\
0.83]\end{array}$ & {$[0.81,0.83]$} & {$[0.76,0.87]$} & {$[0.76,0.86]$} \\
\hline $\begin{array}{l}\text { Family rules for doing } \\
\text { homework }\end{array}$ & $\begin{array}{l}{[0.92} \\
0.93]\end{array}$ & {$[0.92,0.93]$} & {$[0.87,0.95]$} & {$[0.90,0.95]$} \\
\hline $\begin{array}{l}\text { Family rules for doing } \\
\text { household chores }\end{array}$ & $\begin{array}{l}{[0.88} \\
0.89]\end{array}$ & {$[0.87,0.89]$} & {$[0.89,0.96]$} & {$[0.90,0.95]$} \\
\hline $\begin{array}{l}\text { Family rules for watching } \\
\text { television }\end{array}$ & $\begin{array}{l}{[0.63} \\
0.66]\end{array}$ & {$[0.63,0.66]$} & {$[0.55,0.72]$} & {$[0.65,0.74]$} \\
\hline
\end{tabular}

Note: Table values represent averaged estimates from five imputed datasets.

${ }^{1}$ Includes students receiving a certificate of attendance, and those still enrolled in high school in 2006. Students receiving certificates of attendance and those still enrolled in high school in 2006 represent approximately one percent of the unweighted study sample. 
Table A-2

95\% confidence intervals for mean estimates of parents' aspirations for their tenth grader's postsecondary education, by race/ethnicity and SES

\begin{tabular}{lc}
\hline Student Characteristic & $\begin{array}{c}\text { Parents' } \\
\text { aspirations for } \\
\text { their 10th grader's } \\
\text { postsecondary } \\
\text { education }\end{array}$ \\
\hline Race/ethnicity & {$[95 \%$ CI $]$} \\
White & {$[5.19,5.27]$} \\
American Indian/Alaska Native & {$[4.82,5.49]$} \\
Asian/Pacific Islander & {$[5.69,5.83]$} \\
Black & {$[5.47,5.63]$} \\
Hispanic & {$[5.27,5.42]$} \\
Two or more races & {$[5.18,5.46]$} \\
Socioeconomic Status (SES) Quartile & \\
Lowest quartile & {$[4.96,5.09]$} \\
Second quartile & {$[5.12,5.24]$} \\
Third quartile & {$[5.35,5.44]$} \\
Highest quartile & {$[5.66,5.74]$} \\
\hline
\end{tabular}

Note: Table values represent averaged estimates from five imputed datasets.

${ }^{1}$ Based on (BYPARASP) How far in school the parent wants their tenth grader to go, where $1=$ Less than high school graduation

$2=$ High school graduation or GED only

$3=$ Attend or complete 2 -year college/school

$4=$ Attend college, 4-year degree incomplete

$5=$ Graduate from college

$6=$ Obtain Master's degree or equivalent

$7=$ Obtain $\mathrm{PhD}, \mathrm{MD}$, or other advanced degree 
Table A-3

95\% confidence intervals for percentage estimates of spring 2002 sophomores whose parents aspired for them to attain a bachelor's degree or higher, by race/ethnicity and SES

Percentage of tenth graders whose parents aspired for them to attain a

Student Characteristic bachelor's degree or higher ${ }^{1}$

Total $[95 \% \mathrm{CI}]$ [85.51, 87.29]

Race/ethnicity

White

American Indian/Alaska Native

Asian/Pacific Islander

Black

Hispanic

Two or more races

$[80.25,88.23]$

Socioeconomic Status (SES) Quartile

Lowest quartile

Second quartile

Third quartile

Highest quartile $[95.07,96.82]$

Note: Table values represent averaged estimates from five imputed datasets.

${ }^{1}$ Based on (BYPARASP) How far in school the parent wants their tenth grader to go. Categories 5, 6 , and 7 (see descriptions below) were combined to produce these estimates.

$1=$ Less than high school graduation

$2=$ High school graduation or GED only

$3=$ Attend or complete 2 -year college/school

$4=$ Attend college, 4-year degree incomplete

$5=$ Graduate from college

$6=$ Obtain Master's degree or equivalent

$7=$ Obtain PhD, MD, or other advanced degree 


\section{About the Author}

Terris Ross, Ph.D.

Division Leader, P-12 Research \& Evaluation, U.S. Department of Education terrisross@yahoo.com

Terris Ross leads the elementary and secondary division of the Policy and Program Studies Service (PPSS) at the U.S. Department of Education. There, she provides technical guidance and direction for national educational research activities, primarily in the areas of school accountability and student assessment, data analysis and reporting, and the use of data for policy decisions. Prior to joining PPSS, Terris served as an education statistician on the Annual Reports team at the National Center for Education Statistics (NCES), where she was lead author and principal researcher on the congressionally-mandated Higher Education: Gaps in Access and Persistence Study, a report which examined the lack of access to and persistence in college of males from underrepresented racial/ethnic groups. Before joining the U.S. Department of Education, Terris led the Assessment, Evaluation, and Development office in Henry County Schools, GA, as well as serving the Georgia Department of Education as lead analyst for the School Improvement Division. Terris holds bachelor's and master's of science degrees in mathematics from Clark Atlanta University, a specialist degree in Educational Leadership from Florida Atlantic University, and a Ph.D. in educational policy studies with a concentration in research, measurement and statistics from Georgia State University.

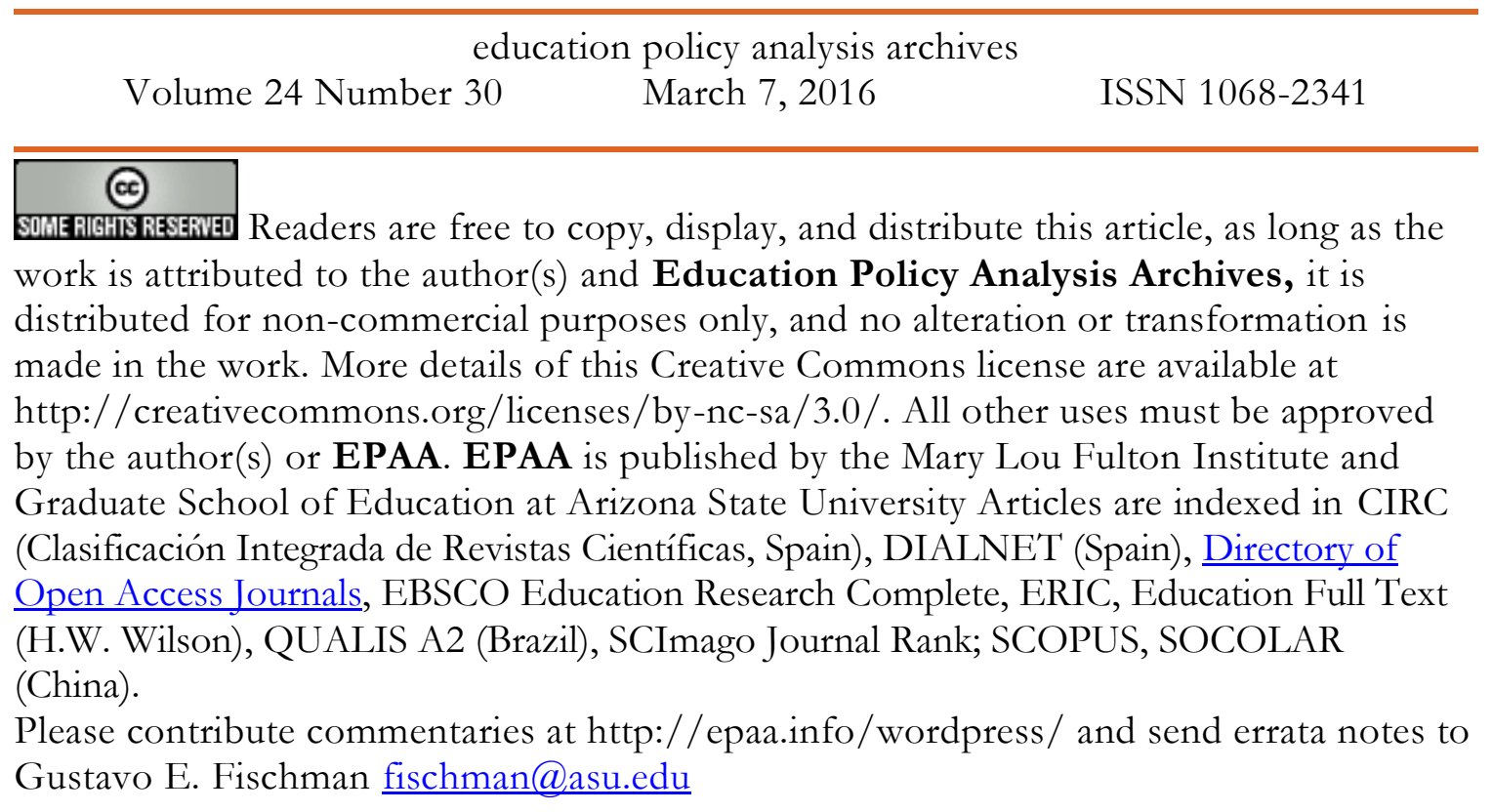

Join EPAA's Facebook community at https://www.facebook.com/EPAAAAPE and Twitter feed @epaa_aape. 


\author{
Casey Cobb University of \\ Connecticut
}

Arnold Danzig San Jose State

University

Linda Darling-Hammond

Stanford University

Elizabeth H. DeBray University of Georgia

Chad d'Entremont Rennie Center for Education Research \& Policy

John Diamond University of Wisconsin, Madison

Matthew Di Carlo Albert Shanker Institute

Michael J. Dumas University of California, Berkeley

Kathy Escamilla University of Colorado, Boulder

Melissa Lynn Freeman Adams State College

Rachael Gabriel

University of Connecticut

Amy Garrett Dikkers University of North Carolina, Wilmington

Gene V Glass Arizona

State University

education policy analysis archives

editorial board

Lead Editor: Audrey Amrein-Beardsley (Arizona State University)

Ronald Glass University of

California, Santa Cruz

Jacob P. K. Gross University of Louisville

Eric M. Haas WestEd

Julian Vasquez Heilig California State University, Sacramento

Kimberly Kappler Hewitt University of North Carolina Greensboro

Aimee Howley Ohio University

Steve Klees University of Maryland

Jaekyung Lee

SUNY Buffalo

Jessica Nina Lester

Indiana University

Amanda E. Lewis University of Illinois, Chicago

Chad R. Lochmiller Indiana

University

Christopher Lubienski University of Illinois, Urbana-Champaign

Sarah Lubienski University of Illinois, Urbana-Champaign

William J. Mathis University of Colorado, Boulder

Michele S. Moses University of Colorado, Boulder

Julianne Moss Deakin

University, Australia

Sharon Nichols University of Texas, San Antonio

Eric Parsons University of Missouri-Columbia

Susan L. Robertson Bristol University, UK

Gloria M. Rodriguez

University of California, Davis
R. Anthony Rolle University of Houston A. G. Rud Washington State
University

Patricia Sánchez University of University of Texas, San Antonio Janelle Scott University of California, Berkeley Jack Schneider College of the Holy Cross

Noah Sobe Loyola University

Nelly P. Stromquist University of Maryland

Benjamin Superfine University of Illinois, Chicago

Maria Teresa Tatto

Michigan State University

Adai Tefera Virginia

Commonwealth University

Tina Trujillo University of California, Berkeley

Federico R. Waitoller University of Illinois, Chicago

Larisa Warhol

University of Connecticut

John Weathers University of Colorado, Colorado Springs

Kevin Welner University of Colorado, Boulder

Terrence G. Wiley Center for Applied Linguistics

John Willinsky

Stanford University

Jennifer R. Wolgemuth University of South Florida

Kyo Yamashiro Claremont Graduate University 
archivos analíticos de políticas educativas

consejo editorial

Editor Ejecutivo: Gustavo E. Fischman (Arizona State University)

Editores Asociados: Armando Alcántara Santuario (Universidad Nacional Autónoma de México), Jason

Beech, (Universidad de San Andrés), Antonio Luzon, Universidad de Granada

Claudio Almonacid

Universidad Metropolitana de

Ciencias de la Educación, Chile

Miguel Ángel Arias Ortega

Universidad Autónoma de la Ciudad

de México

Xavier Besalú Costa

Universitat de Girona, España

Xavier Bonal Sarro Universidad

Autónoma de Barcelona, España

Antonio Bolívar Boitia Universidad de Granada, España

José Joaquín Brunner Universidad Diego Portales, Chile

Damián Canales Sánchez Instituto Nacional para la Evaluación de la Educación, México

Gabriela de la Cruz Flores

Universidad Nacional Autónoma de México

Marco Antonio Delgado Fuentes Universidad Iberoamericana, México

Inés Dussel, DIE-CINVESTAV, México

Pedro Flores Crespo Universidad Iberoamericana, México

Ana María García de Fanelli Centro de Estudios de Estado y Sociedad (CEDES) CONICET, Argentina

\section{Juan Carlos González \\ Faraco Universidad de Huelva, España \\ María Clemente Linuesa \\ Universidad de Salamanca, España \\ Jaume Martínez Bonafé \\ Universitat de València, España}

Alejandro Márquez

Jiménez Instituto de

Investigaciones sobre la

Universidad y la Educación, UNAM, México

María Guadalupe Olivier

Tellez, Universidad

Pedagógica Nacional, México

Miguel Pereyra Universidad

de Granada, España

Mónica Pini Universidad

Nacional de San Martín,

Argentina

\section{Omar Orlando Pulido \\ Chaves Instituto para la Investigación Educativa y el \\ Desarrollo Pedagógico (IDEP)}

José Luis Ramírez Romero

Universidad Autónoma de

Sonora, México

Paula Razquin Universidad

de San Andrés, Argentina

José Ignacio Rivas Flores

Universidad de Málaga, España
Miriam Rodríguez Vargas

Universidad Autónoma de

Tamaulipas, México

José Gregorio Rodríguez

Universidad Nacional de Colombia, Colombia

Mario Rueda Beltrán Instituto de Investigaciones sobre la

Universidad y la Educación, UNAM, México

José Luis San Fabián Maroto

Universidad de Oviedo,

España

Jurjo Torres Santomé, Universidad de la Coruña, España

Yengny Marisol Silva Laya

Universidad Iberoamericana, México

Juan Carlos Tedesco Universidad Nacional de San Martín, Argentina

Ernesto Treviño Ronzón

Universidad Veracruzana, México

Ernesto Treviño Villarreal

Universidad Diego Portales

Santiago, Chile

Antoni Verger Planells

Universidad Autónoma de

Barcelona, España

Catalina Wainerman

Universidad de San Andrés,

Argentina

Juan Carlos Yáñez Velazco

Universidad de Colima, México 
conselho editorial

Editor Executivo: Gustavo E. Fischman (Arizona State University)

Editoras Associadas: Geovana Mendonça Lunardi Mendes (Universidade do Estado de Santa Catarina), Marcia Pletsch, Sandra Regina Sales (Universidade Federal Rural do Rio de Janeiro)

\begin{tabular}{|c|}
\hline Almerindo Afonso \\
\hline Universidade do Minho \\
\hline Portugal \\
\hline Rosanna Maria Barros Sá \\
\hline Universidade do Algarve \\
\hline Portugal \\
\hline Maria Helena Bonilla \\
\hline Universidade Federal da Bahia \\
\hline Brasil \\
\hline Rosa Maria Bueno Fischer \\
\hline $\begin{array}{l}\text { Universidade Federal do Rio Grande } \\
\text { do Sul, Brasil }\end{array}$ \\
\hline Alice Casimiro Lopes \\
\hline Universidade do Estado do Rio de \\
\hline Janeiro, Brasil \\
\hline Suzana Feldens Schwertner \\
\hline Centro Universitário Univates \\
\hline Brasil \\
\hline Flávia Miller Naethe Motta \\
\hline $\begin{array}{l}\text { Universidade Federal Rural do Rio de } \\
\text { Janeiro, Brasil }\end{array}$ \\
\hline
\end{tabular}

Almerindo Afonso

Alexandre Fernandez Vaz

Universidade Federal de Santa

Catarina, Brasil

\section{Regina Célia Linhares Hostins \\ Universidade do Vale do Itajaí, Brasil}

Alfredo Macedo Gomes
Universidade Federal de Pernambuco
Brasil

Jefferson Mainardes

Universidade Estadual de Ponta

Grossa, Brasil

\section{Jader Janer Moreira Lopes}

Universidade Federal Fluminense e

Universidade Federal de Juiz de Fora,

Brasil

Debora Nunes

Universidade Federal do Rio Grande do Norte, Brasil

\section{Alda Junqueira Marin \\ Pontifícia Universidade Católica de \\ São Paulo, Brasil}

\section{Dalila Andrade Oliveira}

Universidade Federal de Minas

Gerais, Brasil
José Augusto Pacheco

Universidade do Minho, Portugal

Jane Paiva

Universidade do Estado do Rio de Janeiro, Brasil

Paulo Alberto Santos Vieira

Universidade do Estado de Mato

Grosso, Brasil

Fabiany de Cássia Tavares Silva Universidade Federal do Mato

Grosso do Sul, Brasil

António Teodoro

Universidade Lusófona

Portugal

\section{Lílian do Valle}

Universidade do Estado do Rio de Janeiro, Brasil

\section{Alfredo Veiga-Neto}

Universidade Federal do Rio

Grande do Sul, Brasil 